Prepared in cooperation with the Cities of Damascus, Gresham, Happy Valley, Milwaukie, and Portland; Clackamas County Water Environment Services; Multnomah County; and the East Multnomah Soil and Water Conservation District

\title{
Suspended-Sediment Characteristics of the Johnson Creek Basin, Oregon, Water Years 2007-10
}

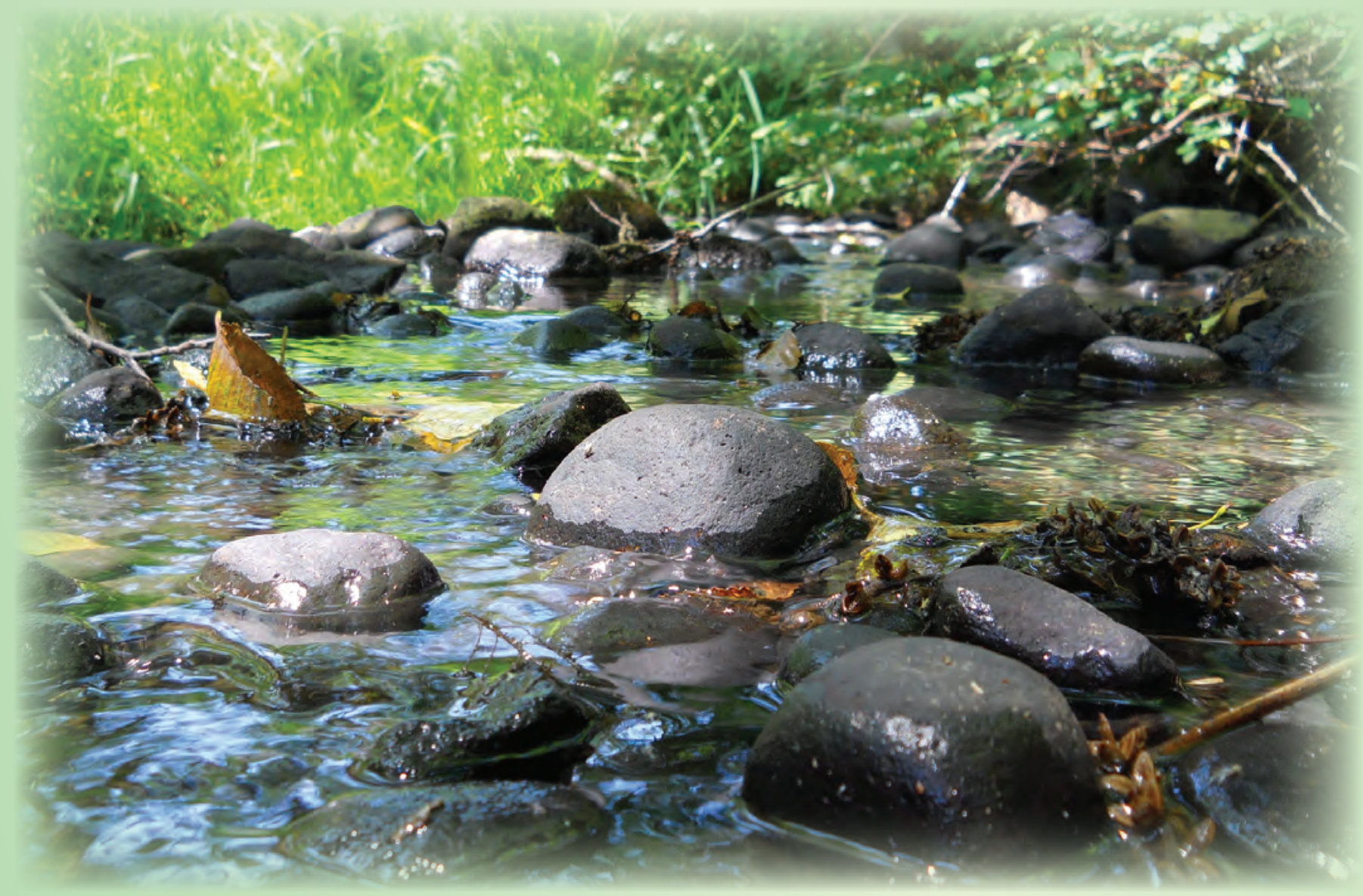

Scientific Investigations Report 2012-5200 
Cover: Sunshine Creek near confluence with Johnson Creek, Oregon, looking upstream. (Photograph taken by Adam Stonewall, U.S. Geological Survey, July 6, 2011.) 


\section{Suspended-Sediment Characteristics of the Johnson Creek Basin, Oregon, Water Years 2007-10}

By Adam J. Stonewall and Heather M. Bragg

Prepared in cooperation with the Cities of Damascus, Gresham, Happy Valley, Milwaukie, and Portland; Clackamas County Water Environment Services; Multnomah County; and the East Multnomah Soil and Water Conservation District

Scientific Investigations Report 2012-5200 


\section{U.S. Department of the Interior \\ KEN SALAZAR, Secretary \\ U.S. Geological Survey \\ Marcia K. McNutt, Director}

U.S. Geological Survey, Reston, Virginia: 2012

For more information on the USGS - the Federal source for science about the Earth, its natural and living resources, natural hazards, and the environment, visit http://www.usgs.gov or call 1-888-ASK-USGS.

For an overview of USGS information products, including maps, imagery, and publications, visit http://www.usgs.gov/pubprod

To order this and other USGS information products, visit http://store.usgs.gov

Any use of trade, product, or firm names is for descriptive purposes only and does not imply endorsement by the U.S. Government.

Although this report is in the public domain, permission must be secured from the individual copyright owners to reproduce any copyrighted materials contained within this report.

Suggested citation:

Stonewall, A.J., and Bragg, H.M., 2012, Suspended-sediment characteristics for the Johnson Creek basin, Oregon, water years 2007-10: U.S. Geological Survey Scientific Investigations Report 2012-5200, 32 p. 


\section{Contents}

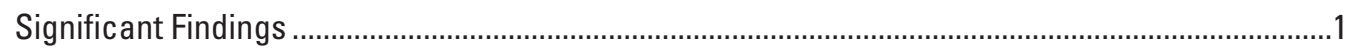

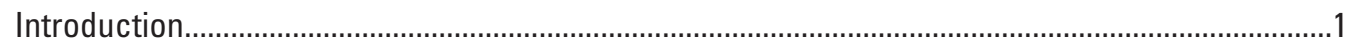

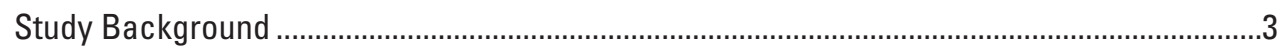

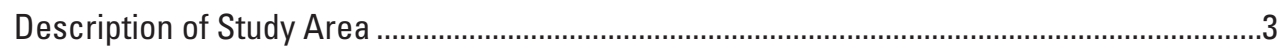

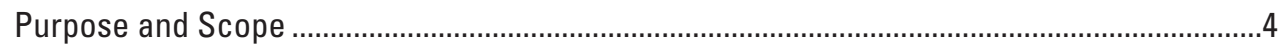

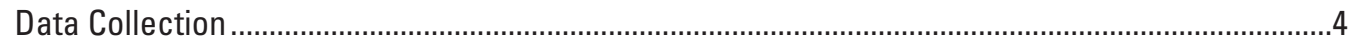

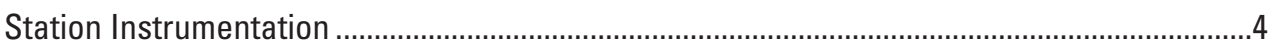

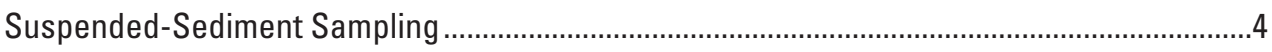

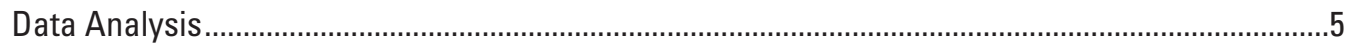

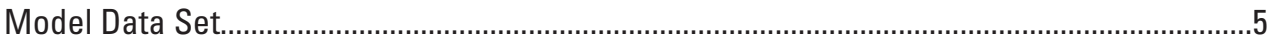

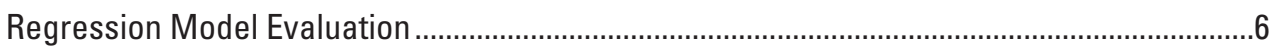

Estimation of Missing or Erroneous Data ................................................................................

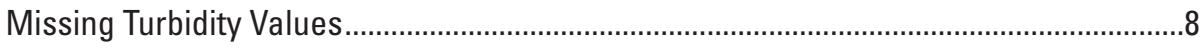

Missing Streamflow Values .................................................................................

Computation of Suspended-Sediment Concentration ........................................................11

Computation of Suspended-Sediment Discharge and Load ..................................................11

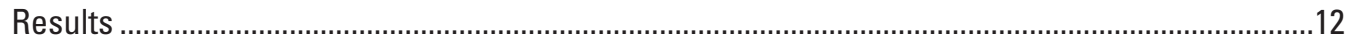

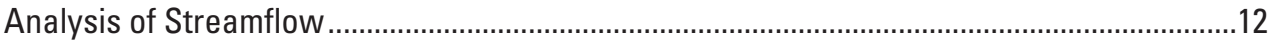

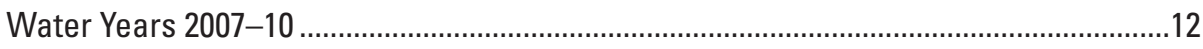

Selected Peak Streamflow Events.............................................................................14

Spatial Distribution of Streamflow.............................................................................14

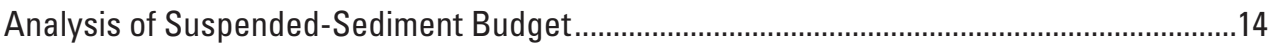

Annual Suspended-Sediment Loads and Yields ...........................................................17

Seasonal Timing of Suspended-Sediment Loads ..........................................................19

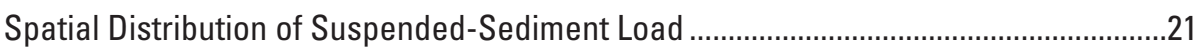

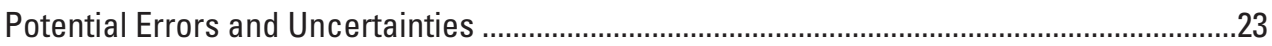

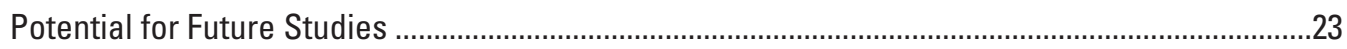

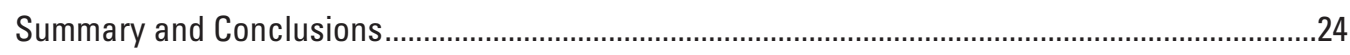

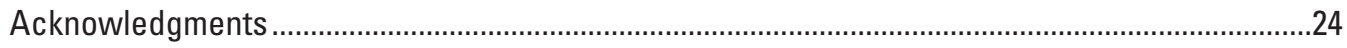

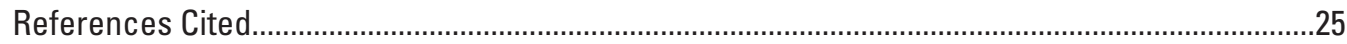

Appendix A. Model-Calibration Data Set for Johnson Creek at Regner Road at Gresham, Oregon, January 2006-January 2009 ............................................................................29

Appendix B. Model-Calibration Data Set for Johnson Creek at Milwaukie, Oregon, December 2005-January 2009....................................................................................................

Appendix C. Regression Model Evaluation ............................................................................... 


\section{Figures}

Figure 1. Map showing location of study area and streamflow-gaging stations used for temperature and turbidity monitoring, Johnson Creek basin, Oregon $\ldots \ldots \ldots \ldots \ldots 2$

Figure 2. Photograph of DH-59 suspended-sediment sampler and collection bottles ........ 5

Figure 3. Graph showing relation between measured suspended-sediment concentration and computed suspended-sediment concentration for model 6 at Gresham (14211400) and Milwaukie (14211550) streamflow-gaging stations, Johnson Creek basin, Oregon, water years 2007-10.

Figure 4. Graphs showing daily streamflow and turbidity at Johnson Creek at Regner Road at Gresham, Oregon (station 14211400), water years 2007-10

Figure 5. Graphs showing daily streamflow and turbidity at Johnson Creek at Milwaukie, Oregon (station 14211550), water years 2007-10

Figure 6. Graphs showing computed monthly suspended-sediment loads for the Gresham (14211400) and Milwaukie (14211550) streamflow-gaging stations, Johnson Creek basin, Oregon, water years 2007-10

Figure 7. Graph showing computed annual suspended-sediment loads for the Gresham (14211400) and Milwaukie (14211550) streamflow-gaging stations, Johnson Creek basin, Oregon, water years 2007-10

Figure 8. Graph showing cumulative distribution of nonexceedance values of continuous streamflow and suspended-sediment load at the Gresham (14211400) and Milwaukie (14211550) streamflow-gaging stations, Johnson Creek basin, Oregon, water years 2007-10

Figure 9. Graphs showing ratio of monthly suspended-sediment load for the Gresham gaging station to monthly suspended-sediment load for the Milwaukie gaging station, compared to monthly average streamflow at the Sycamore station, Johnson Creek basin, Oregon, water years 2007-10.

\section{Tables}

Table 1. Streamflow-gaging stations used for water-quality monitoring, Johnson Creek basin, Oregon

Table 2. Diagnostic test performance of various regression equations for estimating suspended-sediment concentration to streamflow and turbidity, Johnson Creek basin, Oregon, water years 2007-10

Table 3. Regression models selected to show the relation of streamflow and turbidity to suspended-sediment concentration, Johnson Creek basin, Oregon, water years 2007-10

Table 4. Streamflow statistics for Johnson Creek at Sycamore, Oregon (station 14211500). 13

Table 5. Ratio of monthly streamflow for the Gresham and Milwaukie gaging stations, Johnson Creek basin, Oregon, water years 2007-10

Table 6. Annual and monthly suspended-sediment load for the Gresham and Milwaukie gaging stations, Johnson Creek basin, Oregon, water years 2007-10 15

Table 7. Monthly and average annual suspended-sediment yield for the Gresham and Milwaukie gaging stations, Johnson Creek basin, Oregon, water years 2007-10 ... 18

Table 8. Streamflow and suspended-sediment load statistics for the Gresham and Milwaukie gaging stations, Johnson Creek basin, Oregon, water years 2007-10 ... 19

Table 9. Monthly and annual percentages of suspended-sediment loads originating upstream of the Gresham gaging station, Johnson Creek basin, Oregon, water years $2007-10$ 


\section{Conversion Factors, Datums, and Abbreviations and Acronyms}

Conversion Factors

\begin{tabular}{|c|c|c|}
\hline Multiply & By & To obtain \\
\hline \multicolumn{3}{|c|}{ Length } \\
\hline inch (in.) & 2.54 & centimeter $(\mathrm{cm})$ \\
\hline inch (in.) & 25.4 & millimeter (mm) \\
\hline foot $(\mathrm{ft})$ & 0.3048 & meter $(\mathrm{m})$ \\
\hline mile (mi) & 1.609 & kilometer (km) \\
\hline \multicolumn{3}{|c|}{ Area } \\
\hline square mile $\left(\mathrm{mi}^{2}\right)$ & 259.0 & hectare (ha) \\
\hline square mile $\left(\mathrm{mi}^{2}\right)$ & 2.590 & square kilometer $\left(\mathrm{km}^{2}\right)$ \\
\hline \multicolumn{3}{|c|}{ Volume } \\
\hline acre-foot (acre-ft) & 1,233 & cubic meter $\left(\mathrm{m}^{3}\right)$ \\
\hline acre-foot (acre-ft) & 0.001233 & cubic hectometer $\left(\mathrm{hm}^{3}\right)$ \\
\hline \multicolumn{3}{|c|}{ Flow rate } \\
\hline cubic foot per second $\left(\mathrm{ft}^{3} / \mathrm{s}\right)$ & 0.02832 & cubic meter per second $\left(\mathrm{m}^{3} / \mathrm{s}\right)$ \\
\hline $\begin{array}{l}\text { cubic foot per second per square } \\
\text { mile }\left[\left(\mathrm{ft}^{3} / \mathrm{s}\right) / \mathrm{mi}^{2}\right]\end{array}$ & 0.01093 & $\begin{array}{l}\text { cubic meter per second per square } \\
\text { kilometer }\left[\left(\mathrm{m}^{3} / \mathrm{s}\right) / \mathrm{km}^{2}\right]\end{array}$ \\
\hline \multicolumn{3}{|c|}{ Mass } \\
\hline ton, short $(2,000 \mathrm{lb})$ & 0.9072 & megagram (Mg) \\
\hline ton, long $(2,240 \mathrm{lb})$ & 1.016 & megagram $(\mathrm{Mg})$ \\
\hline ton per square mile (ton $/ \mathrm{mi}^{2}$ ) & 0.3503 & $\begin{array}{l}\text { megagram per square kilometer } \\
\qquad\left(\mathrm{Mg} / \mathrm{km}^{2}\right)\end{array}$ \\
\hline $\begin{array}{l}\text { ton per year per square mile } \\
{\left[(\text { ton } / \mathrm{yr}) / \mathrm{mi}^{2}\right]}\end{array}$ & 0.3503 & $\begin{array}{l}\text { megagram per year per square } \\
\text { kilometer }\left[(\mathrm{Mg} / \mathrm{yr}) / \mathrm{km}^{2}\right]\end{array}$ \\
\hline
\end{tabular}

Temperature in degrees Fahrenheit $\left({ }^{\circ} \mathrm{F}\right)$ may be converted to degrees Celsius $\left({ }^{\circ} \mathrm{C}\right)$ as follows:

$$
{ }^{\circ} \mathrm{C}=\left({ }^{\circ} \mathrm{F}-32\right) / 1.8
$$

Specific conductance is given in microsiemens per centimeter at 25 degrees Celsius $(\mu \mathrm{S} / \mathrm{cm}$ at $\left.25^{\circ} \mathrm{C}\right)$.

Concentrations of chemical constituents in water are given either in milligrams per liter ( $\mathrm{mg} / \mathrm{L}$ ) or micrograms per liter $(\mu \mathrm{g} / \mathrm{L})$.

Datums

Vertical coordinate information is referenced to the North American Vertical Datum of 1988 (NAVD 88).

Horizontal coordinate information is referenced to the North American Datum of 1983 (NAD 83).

Altitude, as used in this report, refers to distance above the vertical datum. 
Abbreviations and Acronyms

\begin{tabular}{cl}
\hline $\begin{array}{c}\text { Abbreviation } \\
\text { or acronym }\end{array}$ & \multicolumn{1}{c}{ Definition } \\
\hline BCF & Bias correction factor \\
EWI & Equal-width increment \\
FNU & Formazin Nephelometric Units \\
MAE & Mean absolute error \\
MAPE & Mean absolute percent error \\
MSPE & Model standard percent error \\
NWIS & National Water Information System \\
RMSE & Root mean squared error \\
SSC & Suspended-sediment concentration \\
SSL & Suspended-sediment load \\
SSY & Suspended sediment yield \\
USGS & U.S. Geological Survey \\
\hline
\end{tabular}




\section{Suspended-Sediment Characteristics of the Johnson Creek Basin, Oregon, Water Years 2007-10}

By Adam J. Stonewall and Heather M. Bragg

\section{Significant Findings}

An analysis of suspended-sediment transport in the Johnson Creek basin, Oregon, during water years 2007-10 indicated that:

- Streamflow characteristics for the 4 years of study were not extremely dry or wet, and represented near-average conditions.

- Computed average annual suspended-sediment loads were 1,890 and 4,640 tons at the Gresham and Milwaukie stations, respectively.

- More than 70 percent of suspended-sediment transport in the watershed occurred during the highflow months of November, December, and January.

- Less than 10 percent of suspended-sediment transport in the watershed occurred during April-October.

- About 50 percent of all suspended-sediment load is transported during the highest 1 percent of streamflows.

- The January 2009 streamflow peak was the third highest in the 70-year record for Johnson Creek. About 50 percent of suspended-sediment transport in water year 2009 occurred in January.
- The drainage area upstream of the Gresham streamflow-gaging station constitutes about 30 percent of the drainage area at the Milwaukie station, but accounted for about 40 percent of the suspended sediment and 45 percent of the streamflow at the Milwaukie station.

- On an annual basis, most of the higher sediment yield at the Gresham station, relative to the Milwaukie station, can be explained by the higher streamflow yield at the Gresham station rather than by higher suspended-sediment concentration.

\section{Introduction}

The U.S. Geological Survey (USGS) in cooperation with the cities of Damascus, Gresham, Happy Valley, Milwaukie, and Portland; Clackamas County Water Environment Services; Multnomah County; and the East Multnomah Soil and Water Conservation District monitors streamflow and water quality at stations in the Johnson Creek basin, Oregon (ig. 1, table 1). Data are recorded, transmitted or collected, stored, and made available on the USGS National Water Information System (NWIS) web site (U.S. Geological Survey, 2011b). These resulting data can be used in evaluating stream waterquality effects of land-use practices and restoration projects, conversion of agricultural or rural land to more urban uses, and modification of urban storm-drain networks. 


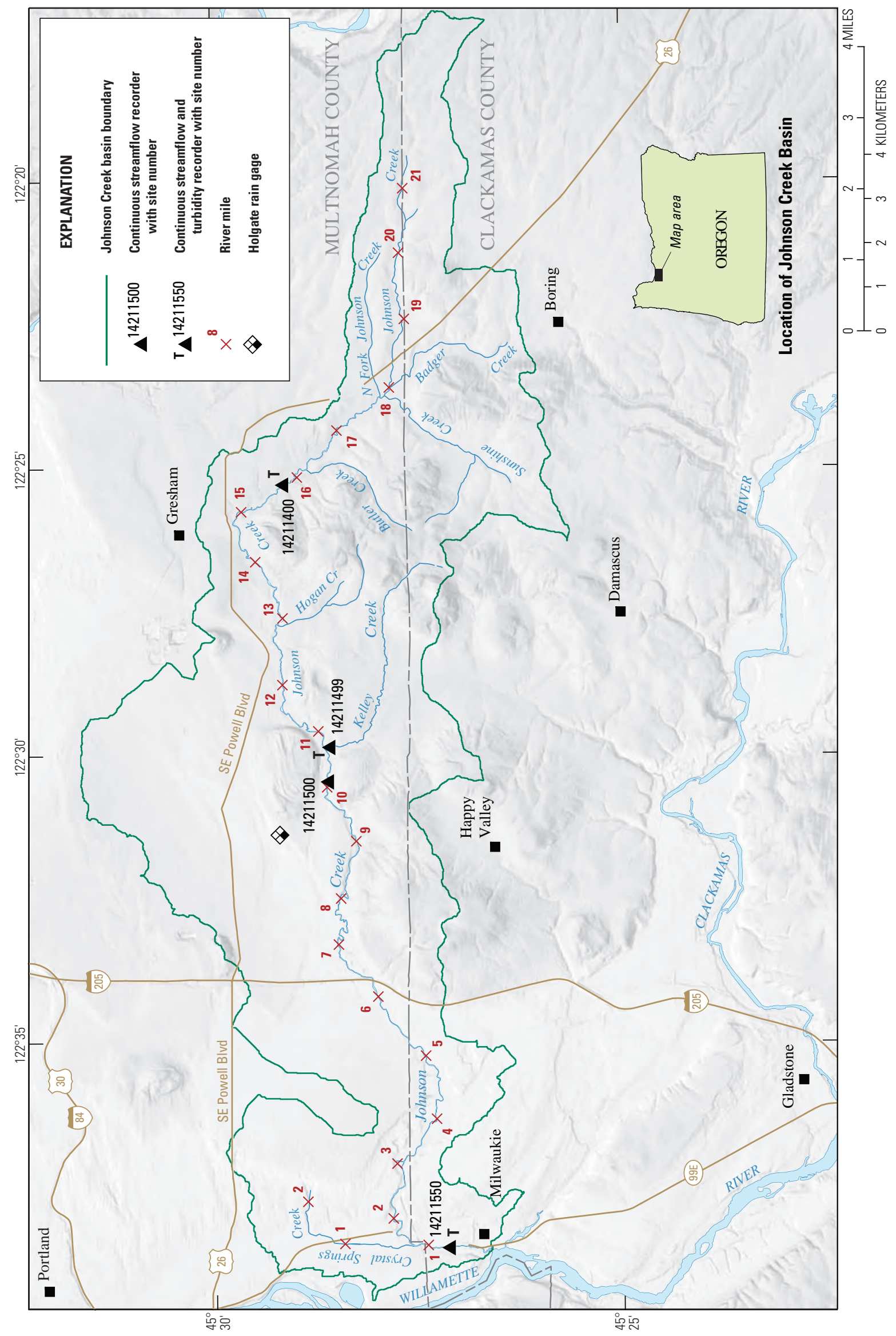

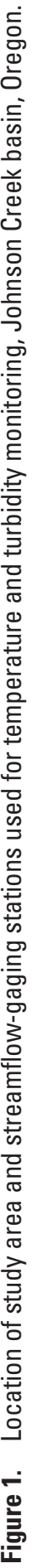


Table 1. Streamflow-gaging stations used for water-quality monitoring, Johnson Creek basin, Oregon.

[Locations of streamflow-gaging stations used for water-quality monitoring are shown in figure 1. Abbreviations: mi ${ }^{2}$, square mile; USGS, U.S. Geological Survey]

\begin{tabular}{cllclll}
\hline \multirow{2}{*}{$\begin{array}{c}\text { USGS } \\
\text { station No. }\end{array}$} & \multicolumn{1}{c}{ Station name } & Station & Drainage & & \multicolumn{3}{c}{ Period of record } \\
\cline { 5 - 7 } & & reference & $\begin{array}{c}\text { area } \\
\left(\mathbf{m i}^{2}\right)\end{array}$ & Streamflow & Temperature & Turbidity \\
\hline 14211400 & Johnson Creek at Reger Road, at Gresham & Gresham & 15.36 & $1999-2010$ & $2000-2010$ & $2005-2010$ \\
14211499 & Kelley Creek at 159th Drive, at Portland & Kelley & 4.69 & $2001-2010$ & $2001-2010$ & starting 2011 \\
14211500 & Johnson Creek at Sycamore & Sycamore & 26.8 & $1941-2010$ & $1999-2010$ & none \\
14211550 & Johnson Creek at Milwaukie & Milwaukie & 53.17 & $1990-2010$ & $1999-2010$ & $2005-2010$ \\
\hline
\end{tabular}

\section{Study Background}

For water years 2007 through 2010 (a water year is the 12-month period between October 1 and September 30), the USGS conducted a study of suspended sediment occurrence and transport in the Johnson Creek basin. Suspended sediment is often an important aspect of water quality in a watershed because it can have adverse effects on fish and other aquatic life (Angino and O'Brien, 1968). The U.S. Environmental Protection Agency (2011) lists sediment as one of the most prevalent sources of impairment in surface waters of the United States.

Past water-quality studies in Johnson Creek included analyses and interpretation of chemical and physical characteristics (alkalinity, dissolved oxygen, $\mathrm{pH}$, specific conductance, and temperature), nutrients, trace elements, anthropogenic organic compounds, and sediment during high- and low-flow periods (Edwards, 1992, 1994; Edwards and Curtiss, 1993). As part of a larger Willamette River basin study, Anderson and others (1996) sampled Johnson Creek for organic compounds, suspended sediment, and trace elements. Similarly, as part of a larger Columbia River basin study, McCarthy and Gale (1999) assessed the distribution of organic compounds using semipermeable membrane devices. Tanner and Lee (2004) evaluated the presence of organochlorine pesticides in whole-water samples from several locations in the Johnson Creek basin, including the temporal variations in the relation between suspended sediment and pesticides.

Suspended-sediment concentration (SSC) time-series data traditionally have been derived from laboratory analyses of water samples (Edwards and Glysson, 1999), and suspendedsediment load (SSL) has been computed using SSC and streamflow time series (Porterfield, 1972). This approach relies, in part, on interpolation of SSCs and streamflows between measurements using hydrologic judgment.

Consequently, results are somewhat subjective and not easily reproduced by others.

Turbidity is an expression of the optical properties of a sample of water (Anderson, 2005). The presence of dissolved and suspended material (clays, silt, fine organic matter, and other material) in streamwater typically results in more turbid (less clear) water (ASTM International, 2007). Numerous studies have shown that turbidity values often are highly correlated with SSC values (Walling, 1977; Gilvear and Petts, 1985; Uhrich and Bragg, 2003; Rasmussen and others, 2005; Bragg and others, 2007; Bragg and Uhrich, 2010). By developing a turbidity-SSC regression model at a sampling station, time-series SSCs can be computed from continuous turbidity data. If the turbidity-SSC regression model is deemed adequate, the SSC and streamflow time series can be used to compute SSL (Rasmussen and others, 2009). Using this approach, SSL has been computed successfully in recent USGS studies in Florida (Lietz and Debiak, 2005), Oregon (Bragg and others, 2007; Bragg and Uhrich, 2010), and Virginia (Jastram and others, 2009). This study was an attempt to apply the technique in the Johnson Creek basin to determine whether the turbidity-SSC correlation exists there, and, if so, to use the technique to help calculate SSL and locate sediment sources in the watershed. The purpose of the study also was to calculate a suspended-sediment budget for the study period 2007-10.

\section{Description of Study Area}

The Johnson Creek basin (fig. 1) is in northwestern Oregon, on the eastern side of the Portland metropolitan area. The creek forms a wildlife and recreational corridor through densely populated areas in the cities of Gresham, Milwaukie, and Portland, and through agricultural and rural areas of Clackamas and Multnomah Counties.

Johnson Creek is about $24 \mathrm{mi}$ long and has a topographic, surface-water drainage area of about $54 \mathrm{mi}^{2}$. The headwaters are in northern Clackamas County, northeast of the city of Boring. The watershed elevation ranges from a low of about $8 \mathrm{ft}$, at the confluence with the Willamette River, to near $1,130 \mathrm{ft}$, at one of the volcanic buttes in the southern part of the watershed (U.S. Geological Survey, 2011a).

The Johnson Creek basin has a temperate marine climate, characterized by wet winters with relatively mild temperatures and a dry season from summer to early autumn. Mean (average) annual precipitation in the watershed is about $53 \mathrm{in}$. and ranges from about $40 \mathrm{in}$. at the mouth of Johnson Creek to more than $60 \mathrm{in}$. at higher elevations to the east (U.S. Geological Survey, 2011a). Historically, about two-thirds of the annual precipitation falls during November-March 
(U.S. Geological Survey, 2011d). The summer months of June-September typically account for about 12 percent of annual precipitation. Most precipitation falls as rain, although periodic snow accumulation is not uncommon at higher elevations. Snowpack in most of the watershed is short-lived, as it usually melts rapidly in subsequent rain events.

The watershed is 65 percent urban and 22 percent forested. The remainder of the watershed consists of a mixture of agricultural and rural uses (U.S. Geological Survey, 2011a). About 30 percent of the watershed is covered by impervious surfaces (U.S. Geological Survey, 2011a). More information about the hydrology, hydrogeology, and land use of the Johnson Creek basin, including a list of previous investigations in and around the watershed, can be found in Snyder (2008) and Lee and Snyder (2009).

\section{Purpose and Scope}

This report presents the results of an investigation into the occurrence and transport of suspended sediment in the Johnson Creek basin for the water years 2007-10. Objectives of this investigation were to:

1. Evaluate the use of turbidity and (or) streamflow as a surrogate method for quantifying SSL in Johnson Creek, which, if valid, could significantly reduce the cost of future SSC monitoring;

2. Compute the mean annual suspended-sediment budget for the watershed, which could be used for evaluating the efficacy of future restoration efforts, land-use practices, and policies aimed at reducing sediment load; and

3. Investigate the timing and spatial distribution of SSL within the watershed, so that future remediation efforts can focus on when and where sediment transport is most problematic.

The annual and monthly suspended-sediment loads were computed using data from two gaging stations, Johnson Creek at Regner Road, at Gresham (14211400) and Johnson Creek at Milwaukie (14211550). Historical streamflow data from a third long-term station, Johnson Creek at Sycamore (14211500), also were examined. The analysis method included developing regression models relating SSC to turbidity and streamflow, and calculating continuous SSC and SSL for each station.

\section{Data Collection}

Continuous water-quality data were collected by in situ (left in place) water-quality monitoring devices and discrete water-quality data were collected using manual sampling methods. Four streamflow and temperature stations were in operation in the Johnson Creek basin during water years 2007-10, three on Johnson Creek, and one on the largest tributary, Kelley Creek. Of the three on Johnson Creek, two stations contained turbidity probes. The dates and locations of temperature, turbidity, and streamflow monitoring are shown in table 1. All data are available through either the USGS National Water Information System (NWIS) web site (U.S. Geological Survey, 2011b) or the project web site (U.S. Geological Survey, 2011c).

\section{Station Instrumentation}

Turbidity was monitored using a McVan Analite ${ }^{\circledR}$ NEP 395 probe at each station. The maximum upper range of the Analite ${ }^{\circledR}$ probe is 1,000 Formazin Nephelometric Units (FNU) (International Organization for Standardization, 1999; Anderson, 2005). Recorded turbidity values compared favorably with a calibrated field turbidity meter and never exceeded the upper range of the instrument. Periodic crosssectional measurements were made with field turbidity meters. These measurements showed little variation throughout the cross sections at Gresham and Milwaukie, suggesting wellmixed channels. Temperature data also were collected at each station and used for quality control. Streamflow data were collected in accordance with the maintenance and evaluation protocols outlined by Rantz and others (1982) and Kennedy (1984).

Data at the Milwaukie station (14211550) were collected in 30-min increments. The Gresham station (14211400) is prone to more rapid changes in streamflow and turbidity than the Milwaukie station. Consequently, data were collected at this station in 15-min increments. The data from both stations were uploaded to the USGS NWIS several times per day by phone or satellite telemetry.

\section{Suspended-Sediment Sampling}

Suspended-sediment samples were collected periodically from water year 2005 to 2010 at the Milwaukie and Gresham gaging stations. Samples were collected primarily during large storm events, when SSCs were highest, using the standard USGS method for the equal-width-increment (EWI) method (Edwards and Glysson, 1999). Most samples were collected using a US DH-48, DH-59, DH-74 or DH-77 sampler (fig. 2). SSC samples were analyzed at the Cascade Volcano Observatory laboratory (Guy, 1969), and the results were reported in milligrams per liter. Additionally, most samples were analyzed for the percentage of silt and clay, reported as a mass percentage of sediment finer than $62 \mu \mathrm{m}$ in diameter. The resulting data were used to investigate the relation between the optical property of turbidity and the concentration of suspended sediment in the stream (appendixes A and $\underline{B})$. 


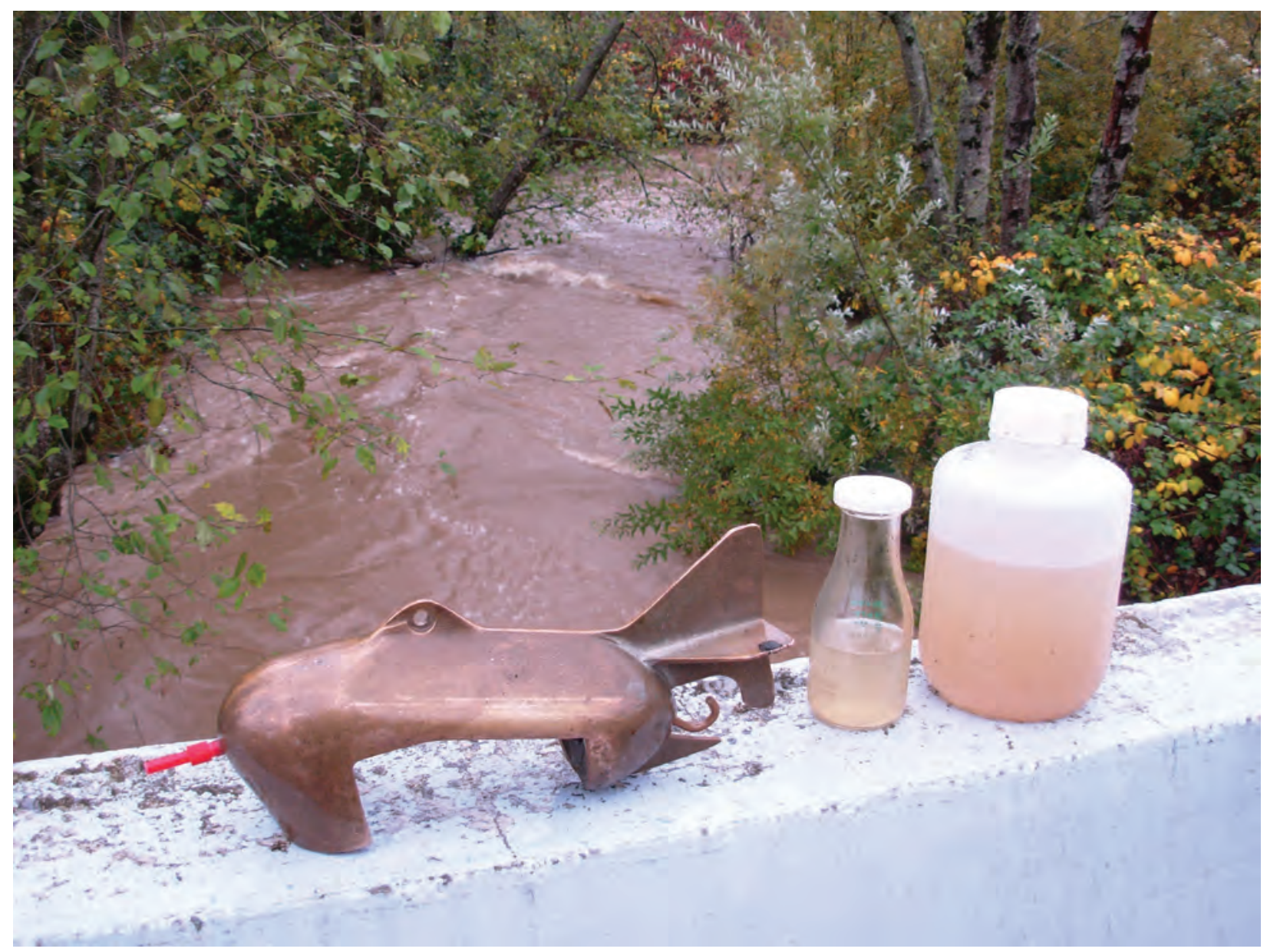

Figure 2. DH-59 suspended-sediment sampler and collection bottles.

\section{Data Analysis}

Suspended sediment, turbidity, and streamflow data from the two Johnson Creek stations were compiled and screened for errors. Several regression models were created for each station and evaluated using diagnostic linear regression statistics. When necessary to provide a complete record, missing data were estimated. The resulting data sets and regression models were used to calculate SSL for water years 2007-10.

\section{Model Data Set}

The data used in the regression analyses were compiled from the SSC values of the physical samples and the continuous streamflow and turbidity data at each station. For the Gresham station, 15-min recorded streamflow and turbidity values were averaged during the period when each suspended-sediment sample was collected. In a similar manner, streamflow and turbidity were averaged using the 30-min recorded data for the Milwaukie station.

The suspended-sediment samples were screened for outliers using the methods outlined in Helsel and Hirsch (2002) and Rasmussen and others (2009). Scatter plots of turbidity compared with SSC identified four samples (two from each station) collected on January 31 and March 13, 2008 , as potential outliers. Subsequent inspection revealed a laboratory error, and these samples were eliminated from further analysis. Samples also were evaluated for the percentage of suspended sediment finer than $62 \mu \mathrm{m}$, which ranged from 88 to 98 percent at Gresham (appendix A), and 81 to 96 percent at Milwaukie (appendix B). An outlier in the percentage of suspended sediment finer than $62 \mu \mathrm{m}$ might suggest problems with the sample. No samples were removed based on this criterion, and all remaining samples for each station were used in the two regression analyses. 


\section{Regression Model Evaluation}

Seven linear regression models were evaluated for each station (table 2). Model 6 was selected for use at both stations based on a comparison of diagnostic linear regression statistics and the evaluation of the linear regression model residuals. The two equations selected and the upper and lower model standard percent error (MSPE) are shown in table 3. MSPE is the root-mean squared error expressed as a percentage (Rasmussen and others, 2009). The relation between measured and computed SSC values using model 6 is shown in figure 3. The two stations show similar degrees of fit, and indicate no evident bias for the range of SSC values. A full review of the regression model selection process is available in appendix $\mathrm{C}$.

Table 2. Diagnostic test performance of various regression equations for estimating suspended-sediment concentration to streamflow and turbidity, Johnson Creek basin, Oregon, water years 2007-10.

[Station reference: Complete station names are shown in table 1 and locations are shown in figure 1. Variables: $\log$, $\log$ base 10; Q, streamflow, in cubic feet per second; Sqrt, square root; SSC, suspended-sediment concentration; T, turbidity, in Formazin Nephelometric Units (FNU). Diagnostic linear regression statistics: Adj $\mathrm{R}^{2}$, adjusted coefficient of determination; RMSE, root mean squared error; MAE, mean absolute error; MAPE, mean absolute percent error. Evaluation of linear regression model residuals: JB, P-value of Jarque-Bera test statistic; BP, P-value of Breusch-Pagan test statistic]

\begin{tabular}{|c|c|c|c|c|c|c|c|c|}
\hline & \multicolumn{2}{|c|}{ Variables } & \multicolumn{4}{|c|}{$\begin{array}{l}\text { Diagnostic linear } \\
\text { regression statistics }\end{array}$} & \multicolumn{2}{|c|}{$\begin{array}{l}\text { Evaluation of linear } \\
\text { regression model residuals }\end{array}$} \\
\hline & Dependent & Independent & Adj $R^{2}$ & RMSE & MAE & MAPE & JB & BP \\
\hline \multicolumn{9}{|c|}{ Gresham } \\
\hline Model 1 & $\mathrm{SSC}$ & $\mathrm{T}$ & 0.81 & 36.5 & 27.2 & 0.22 & 0.125 & 0.056 \\
\hline Model 2 & $\mathrm{SSC}$ & Q & 0.71 & 44.8 & 34.5 & 0.29 & 0.211 & 0.627 \\
\hline Model 3 & $\mathrm{SSC}$ & $\mathrm{Q}, \mathrm{T}$ & 0.90 & 25.3 & 20.8 & 0.16 & 0.261 & 0.001 \\
\hline Model 4 & Log SSC & $\log T$ & 0.86 & 40.8 & 30.4 & 0.21 & 0.230 & 0.007 \\
\hline Model 5 & Log SSC & $\log \mathrm{Q}$ & 0.71 & 47.2 & 37.1 & 0.27 & 0.000 & 0.367 \\
\hline Model 6 & Log SSC & $\log \mathrm{T}, \log \mathrm{Q}$ & 0.94 & 27.1 & 21.3 & 0.14 & 0.175 & 0.001 \\
\hline Model 7 & Sqrt SSC & Sqrt T, Sqrt Q & 0.93 & 25.1 & 20.2 & 0.14 & 0.187 & 0.001 \\
\hline \multicolumn{9}{|c|}{ Milwaukie } \\
\hline Model 1 & $\mathrm{SSC}$ & $\mathrm{T}$ & 0.81 & 45.2 & 37.2 & 0.24 & 0.371 & 0.045 \\
\hline Model 2 & $\mathrm{SSC}$ & Q & 0.45 & 77.1 & 60.5 & 0.47 & 0.873 & 0.922 \\
\hline Model 3 & $\mathrm{SSC}$ & $\mathrm{Q}, \mathrm{T}$ & 0.80 & 45.2 & 37.4 & 0.25 & 0.337 & 0.094 \\
\hline Model 4 & Log SSC & $\log T$ & 0.84 & 47.4 & 38.9 & 0.23 & 0.261 & 0.012 \\
\hline Model 5 & $\log$ SSC & $\log Q$ & 0.59 & 75.5 & 53.4 & 0.33 & 0.913 & 0.804 \\
\hline Model 6 & $\log$ SSC & $\log T, \log Q$ & 0.84 & 51.3 & 41.0 & 0.23 & 0.049 & 0.004 \\
\hline Model 7 & Sqrt SSC & Sqrt T, Sqrt Q & 0.83 & 164 & 128 & 0.23 & 0.335 & 0.016 \\
\hline Both stations & Variables & $\begin{array}{l}\text { Average } \\
\text { rank }\end{array}$ & & & & & & \\
\hline Model 1 & $\mathrm{~T}$ & 3.8 & & & & & & \\
\hline Model 2 & $\mathrm{Q}$ & 6.3 & & & & & & \\
\hline Model 3 & $\mathrm{Q}, \mathrm{T}$ & 2.8 & & & & & & \\
\hline Model 4 & $\log T$ & 3.5 & & & & & & \\
\hline Model 5 & $\log Q$ & 6.3 & & & & & & \\
\hline Model 6 & $\log T, \log Q$ & 2.3 & & & & & & \\
\hline Model 7 & Sqrt T, Sqrt Q & 3.3 & & & & & & \\
\hline
\end{tabular}


Table 3. Regression models selected to show the relation of streamflow and turbidity to suspended-sediment concentration, Johnson Creek basin, Oregon, water years 2007-10.

[Station reference: Complete station names are shown in table 1 and locations are shown in figure 1. Regression model equation: Log, log base 10; Q, streamflow, in cubic feet per second; SSC, suspended-sediment concentration; T, turbidity, in Formazin Nephelometric Units (FNU). Adj R2, adjusted coefficient of determination. MSPE, model standard percent error]

\begin{tabular}{llcccc}
\hline $\begin{array}{c}\text { Station } \\
\text { reference }\end{array}$ & Regression model equation & $\begin{array}{c}\text { Bias- } \\
\text { correction } \\
\text { factor }\end{array}$ & Adj R $^{2}$ & $\begin{array}{c}\text { Upper } \\
\text { MSPE } \\
\text { (percent) }\end{array}$ & $\begin{array}{c}\text { Lower } \\
\text { MSPE } \\
\text { (percent) }\end{array}$ \\
\hline Gresham & $\log _{10} \mathrm{SSC}=0.922 \log _{10} \mathrm{~T}+0.260 \log 10 \mathrm{Q}-0.618$ & 1.01 & 0.94 & 18.4 & -15.6 \\
Milwaukie & $\log _{10} \mathrm{SSC}=1.024 \log _{10} \mathrm{~T}+0.143 \log 10 \mathrm{Q}-0.419$ & 1.03 & 0.84 & 30.4 & -23.3 \\
\hline
\end{tabular}

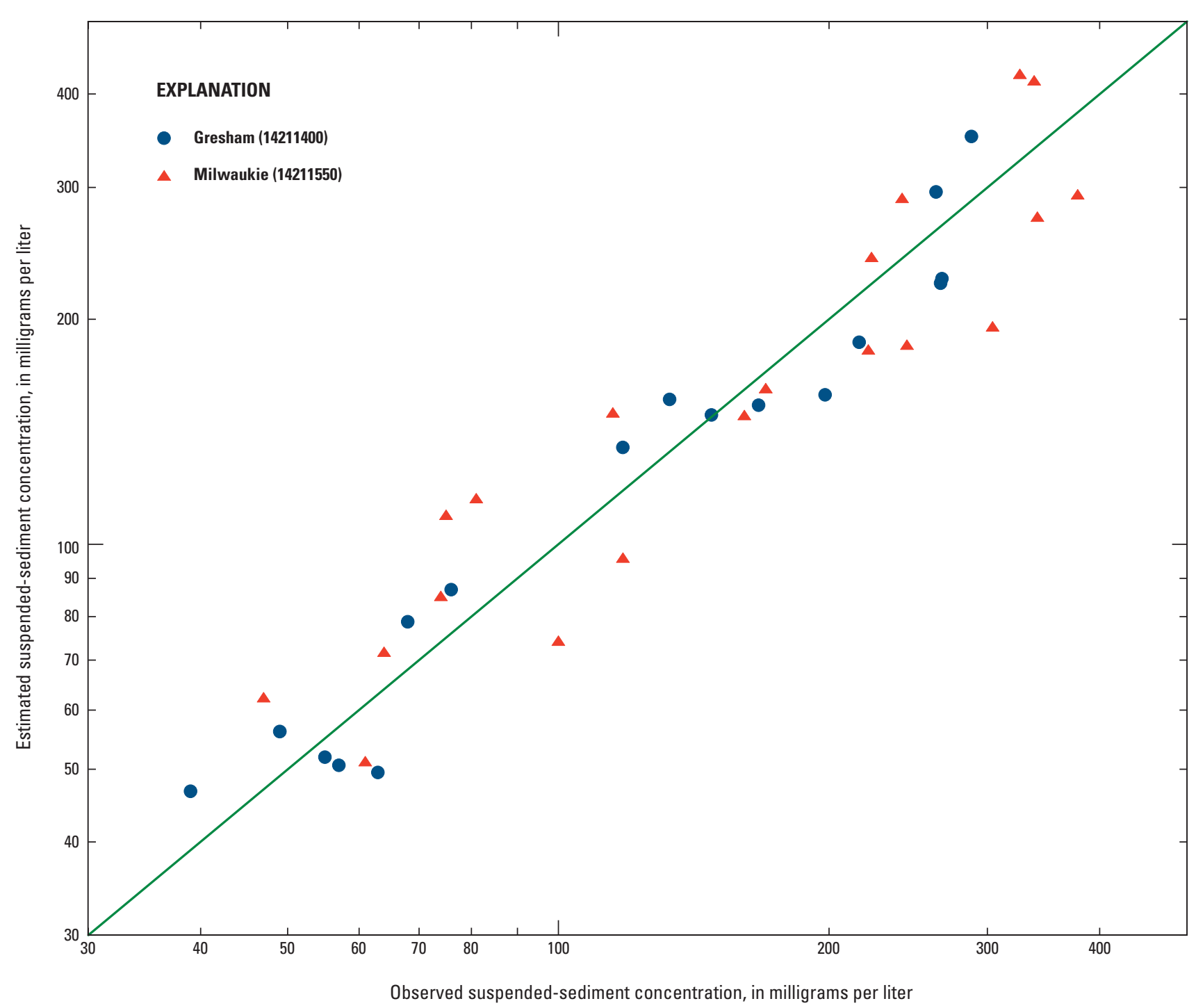

Figure 3. Relation between measured suspended-sediment concentration and computed suspended-sediment concentration for model 6 at Gresham (14211400) and Milwaukie (14211550) streamflow-gaging stations, Johnson Creek basin, Oregon, water years 2007-10. 


\section{Estimation of Missing or Erroneous Data}

Computation of annual SSL requires complete SSC and streamflow records, in regular time increments. Because streamflow and turbidity were used to calculate SSC, a time series of SSL could not be computed for periods missing streamflow or turbidity data. Turbidity time series for the Gresham and Milwaukie stations were incomplete in all 4 water years because of sensor fouling or maintenance issues. Gaps in the streamflow records were less common and typically resulted from freezing conditions or instrumentation issues.

Two methods were considered for estimating SSC values during periods of missing streamflow or turbidity data: (1) SSC values were estimated directly by performing regressions of SSC against whichever time series were available at the two stations, and (2) streamflow and turbidity values were regressed using the same independent variables. These estimated streamflow or turbidity values then were used to estimate SSC values. Both methods benefit from the high correlations between streamflow and turbidity and between turbidity values at the two stations.

To test the effectiveness of both methods, three periods with complete data sets of streamflow and turbidity were selected —one during a high peak, one during a moderate peak, and one during summer low flow. Turbidity values were assumed to be missing for part of all three periods, and SSC values were estimated using both methods. These estimated SSC values then were compared against the SSC values computed using the equations from table 3 , which are considered true values for the purpose of this experiment. The method of estimating SSC values directly tended to underestimate SSC during periods of high flow and overestimate SSC during periods of low flow. Both methods displayed problems with timing during peaks, as turbidity values tend to peak prior to streamflow or SSC values. The second method of estimating streamflow and turbidity was selected based on its relatively higher degree of accuracy. Estimated values of streamflow and turbidity are not saved in NWIS, but are available from the authors upon request.

\section{Missing Turbidity Values}

Missing turbidity values were estimated using linear regression analysis and a simple smoothing algorithm. For each missing period, a regression analysis was performed using streamflow and turbidity data from a relatively narrow time frame before and after the missing period. When needed and available, a multiple linear regression was performed using streamflow data from the station with missing data and turbidity values from the other gaging station. For example, no valid turbidity data were recorded at the Gresham station during October 24-26, 2007, due to fouling of the probe. A multiple linear regression model was developed relating the turbidity values at the Gresham station for October 9-23 and October 27-November 13, 2007, to the Gresham streamflow and Milwaukie turbidity values for those same dates. The adjusted coefficient of determination (Adj $R^{2}$ ) value of this particular model was 0.71 , reflecting the large range in flow and turbidity values and the noise inherent in the turbidity record. Over the 4-year period of this study, this method was used to estimate 35 and 16 percent of the turbidity values at the Gresham and Milwaukie stations, respectively.

The need for continuous turbidity data was most important during autumn and winter, when most suspended sediment was being transported. During summer, warm temperatures and low flow in the stream caused persistent biological fouling of the in situ turbidity probes. Consequently, the probes were removed during the summers of 2009 (Gresham station) and 2010 (Gresham and Milwaukie stations), and re-installed in autumn of those same calendar years. As a result, no turbidity data were recorded at either station during the unexpected June 2010 high streamflow. To estimate turbidity during this period, the regression models were developed using longer time-series variables, encompassing streamflow ranges equal to the high streamflow. The turbidity values estimated during the late spring to early autumn periods account for more than 80 percent of the total number of turbidity values estimated.

\section{Missing Streamflow Values}

Streamflow records were nearly complete for both stations. The Gresham and Milwaukie stations were missing 0.9 and 0.2 percent of streamflow values, respectively. Additionally, 90 percent of missing streamflow data occurred during summer, when streamflow typically varies little and is easiest to estimate. Incomplete streamflow time series commonly were the result of equipment malfunction or routine maintenance. Missing streamflow records were estimated by creating regression models with streamflow records from the other gaging station, and using a simple linear smoothing algorithm. The time series of the downstream station (Milwaukie) was shifted 4 hours to account for time of travel between the two stations, based on an evaluation of which time lag provided the largest coefficient of determination between the two stations. Regression models for streamflow estimation proved to be more accurate than for turbidity estimation, with adjusted $\mathrm{R}^{2}$ values ranging from 0.96 to near 1.0 .

The final time series of streamflow and turbidity at the Gresham and Milwaukie stations are shown in figures 4 and $\underline{5}$, respectively. Estimated streamflow data were not included in figures 4 and $\underline{5}$ because data were insufficient and do not show clearly. There is a slight lag between turbidity and streamflow, but the overall shapes of the hydrographs typically are similar. 


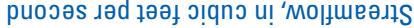

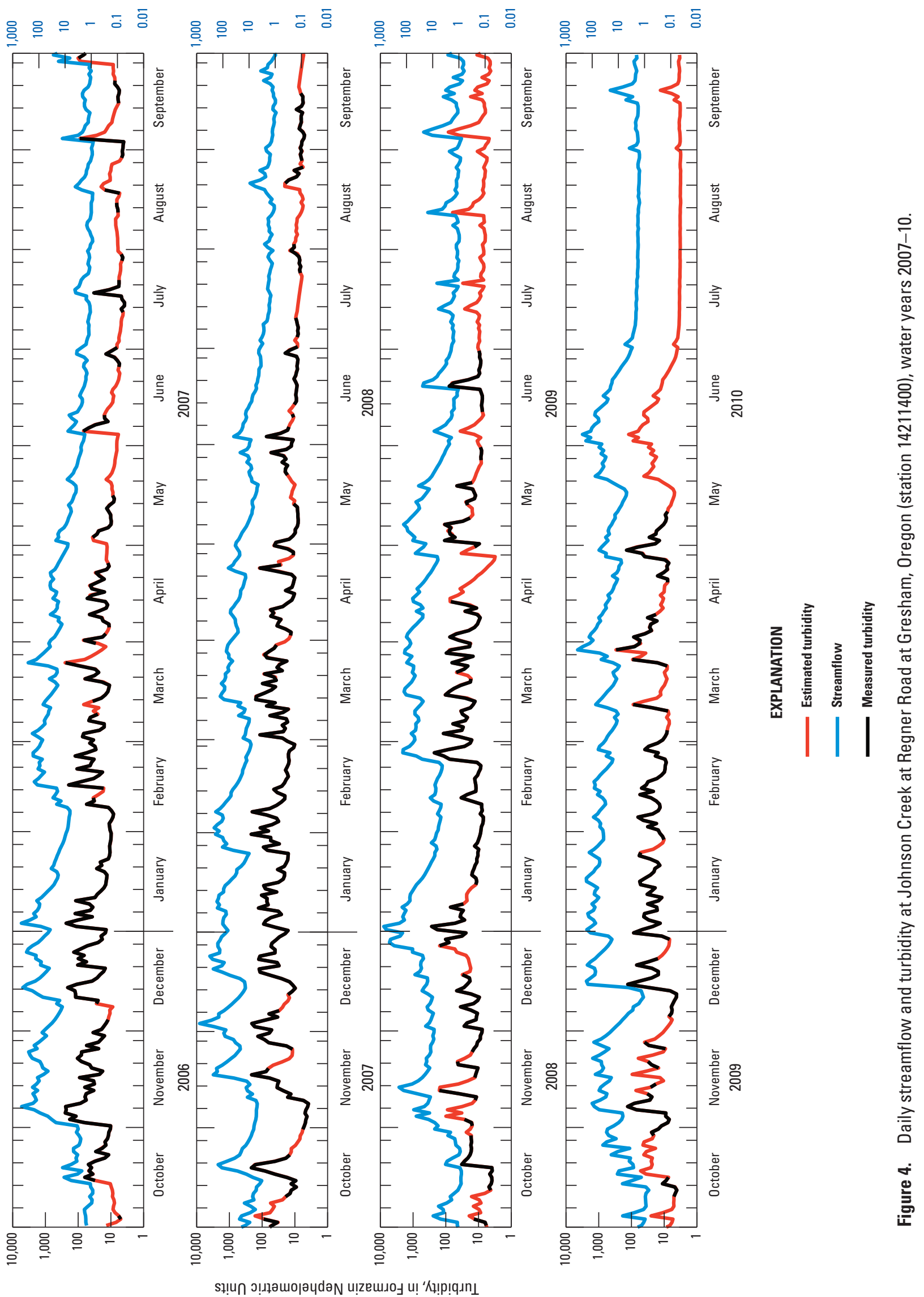




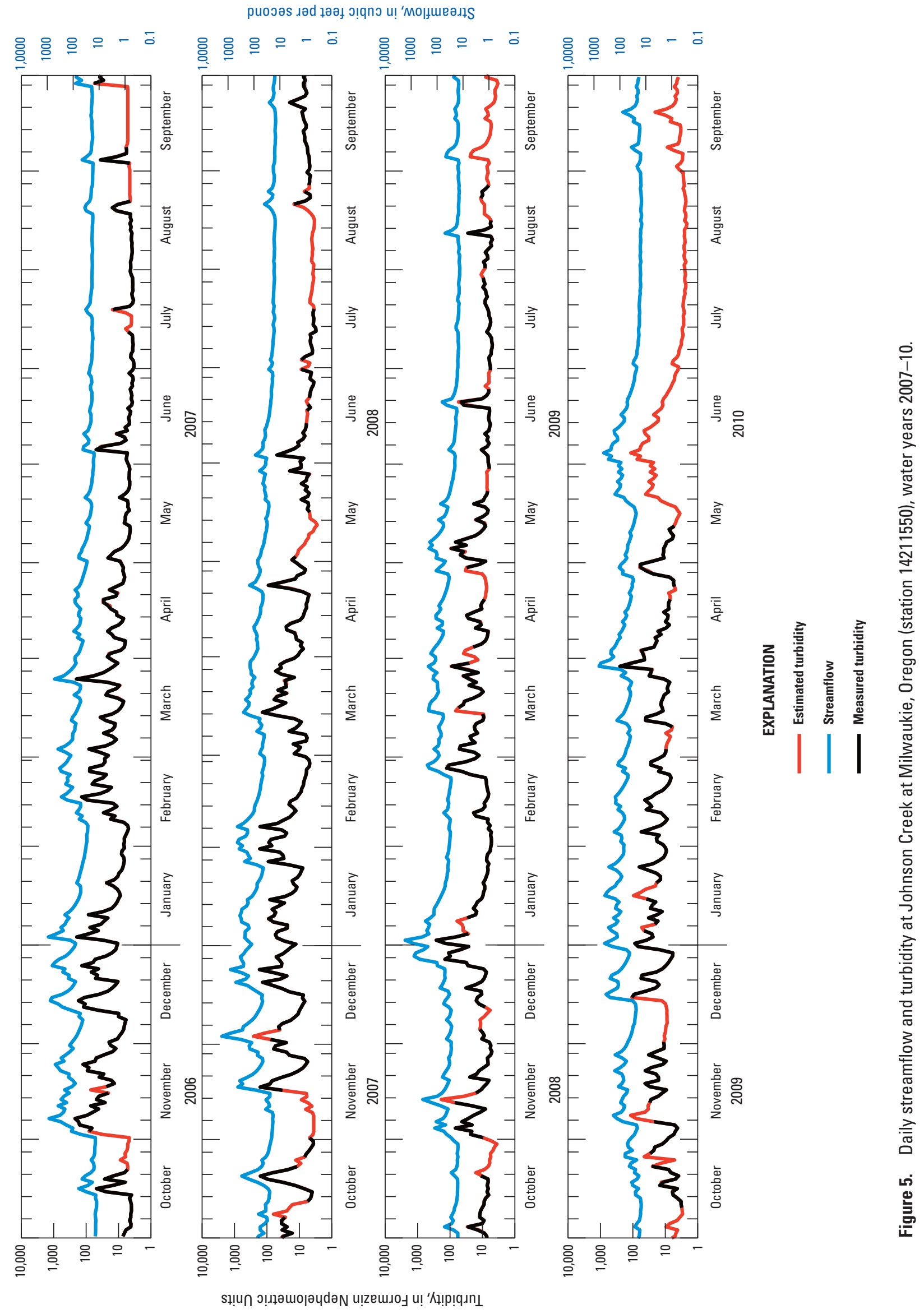




\section{Computation of Suspended-Sediment Concentration}

As described in the section "Data Analysis," regression models were developed to compute continuous SSC time series for each station using the discrete SSC, streamflow, and turbidity data associated with each suspended-sediment sample. The selected regression model equation form was:

$$
\log _{10}(S S C)=a \log _{10}(T)+b \log _{10}(Q)+c
$$

where

$$
\begin{aligned}
& \text { SSC is suspended-sediment concentration, } \\
& \text { in milligrams per liter; } \\
& T \quad \text { is turbidity, in Formazin Nephelometric } \\
& \text { Units; } \\
& Q \quad \text { is streamflow, in cubic feet per second; } \\
& a \text { and } b \text { are the slope coefficients of the regression } \\
& \text { analysis; and } \\
& c \quad \text { is the y-intercept of the regression analysis. }
\end{aligned}
$$

The continuous time series of streamflow and turbidity for each station were input into the equations in table 3 to produce a time series of SSC values for water years 2007-10. The transformation of the resulting SSC values from log to arithmetic space results in a bias of the data (Helsel and Hirsch, 2002). This bias can be reduced by multiplying each SSC value by a bias correction factor (BCF), also known as a "smearing estimator." The Duan BCF (Duan, 1983) was computed as follows:

$$
B C F_{\text {Duan }}=\frac{\sum_{i=1}^{n} 10^{e_{i}}}{n}
$$

where

$$
\begin{aligned}
& B C F_{\text {Duan }} \text { is the bias correction factor; } \\
& e_{i} \quad \text { is the regression residual, in milligrams } \\
& \text { per liter; and } \\
& n \quad \text { is the number of suspended-sediment } \\
& \text { samples. }
\end{aligned}
$$

BCF values used are listed in table 3.

\section{Computation of Suspended-Sediment Discharge and Load}

The annual SSL was computed for each station for water years 2007-10. For the Gresham station, computed 15-min SSC, in milligrams per liter, and corresponding streamflow values, in cubic feet per second, were used to calculate SSL, in tons per 15 min using the following equation:

$$
\mathrm{SSL}=\mathrm{SSC} \times Q \times c_{1}
$$

where

SSL is the computed suspended-sediment load, in tons per 15-min interval;

SSC is the computed suspended-sediment concentration, in milligrams per liter;

$Q \quad$ is the streamflow, in cubic feet per second; and

$c_{1}$ is a constant, 0.0000281 , for converting units to tons per $15 \mathrm{~min}$.

Similarly, SSL was computed for the Milwaukie station in tons per 30 min using the following equation:

$$
\mathrm{SSL}=\mathrm{SSC} \times Q \times c_{2}
$$

where

SSL is the computed suspended-sediment load, in tons per 15-min interval;

SSC is the computed suspended-sediment concentration, in milligrams per liter;

$Q \quad$ is the streamflow, in cubic feet per second; and

$c_{2}$ is a constant, 0.0000562 , for converting units to tons per $15 \mathrm{~min}$.

The daily SSL was computed by summing the 96 or 48 computed 15- or 30-min SSL values per day for Gresham and Milwaukie stations, respectively. The monthly and annual SSL were computed by summing the appropriate daily SSL values. Daily totals of SSL are termed "daily values." The individual 15- or 30-min values for the Gresham and Milwaukie stations are termed "unit values." 


\section{Results}

This study had three major objectives: (1) to evaluate the use of turbidity and (or) streamflow as a surrogate for quantifying SSL in Johnson Creek, (2) to compute the mean annual suspended-sediment budget for the watershed, and (3) to investigate the timing and spatial distribution of SSL in the watershed. Objective 1 was discussed in section, "Regression Model Evaluation." The monthly and annual SSL budgets and the annual streamflow were evaluated to accomplish objectives 2 and 3 .

Analysis of the suspended-sediment budget of Johnson Creek was divided into two major components - streamflow and suspended-sediment loads (SSLs). Because the annual SSL budget for a given water year is heavily influenced by the quantity and flashiness of streamflow for that water year, the streamflow of the 4 water years covered in this study (2007-10) was investigated to determine if the SSL computed should be considered extreme or otherwise unusual.

Because SSL is a product of SSC and streamflow (eqs. 3 and 4), if SSC is fixed in time, SSL is directly proportional to streamflow. Evaluating the amount of streamflow for a given water year should be a good indicator of how much SSL to expect. However, SSC also is closely correlated with streamflow. As a result, during a storm event, the rate of increase in SSL is greater than the rate of increase in streamflow. This relation results in especially large quantities of SSL being transported during yearly peaks and floods. The relation between increasing streamflow and SSL hereafter is termed "disproportionality."

An example of this disproportionality is provided by the storm of late December 2007. The heavy rainfall resulted in the streamflow increasing by a factor of $11, \mathrm{SSC}$ increasing by a factor of 20, and SSL increasing by a factor of 157 . The disproportionality between increases in streamflow and SSL highlights the importance of analyzing the high streamflow periods for any given water year. If enough high peaks occur in a given water year, more SSL might be produced than another water year with greater average annual streamflow but fewer peaks. The extent of this disproportionality is analyzed in further detail in section, "Analysis of Suspended-Sediment Budget."

\section{Analysis of Streamflow}

Streamflow is an important component in the production of SSL. Water years with especially high or low levels of streamflow are likely to produce SSLs that are not representative of average conditions. The streamflow records at the Gresham and Milwaukie stations cover only 12 and 21 years of record, respectively. Conversely, streamflow has been continuously recorded at the Sycamore gaging station (14211500) since water year 1941, providing 70 years of data to be compared with the streamflow for the period of study, water years 2007-10.

The Sycamore station is geographically located between the Gresham and Milwaukie stations. For reference, the Sycamore station has a drainage area of $26.8 \mathrm{mi}^{2}$, which is about 1.75 and 0.50 times the drainage areas of Gresham and Milwaukie, respectively. Similarly, the average annual streamflow at the Sycamore station is $53 \mathrm{ft}^{3} / \mathrm{s}$, which is about 1.75 and 0.70 times the average annual streamflow of Gresham and Milwaukie stations, respectively.

In addition to overall annual and monthly streamflow quantities, two specific peak streamflows are covered in more detail in the section "Selected Peak Streamflow Events." The spatial distribution of streamflow also was investigated by calculating the percentage of streamflow at the Milwaukie station originating upstream of the Gresham station (see the section "Spatial Distribution of Streamflow"). This spatial distribution of streamflow will be compared to the spatial distribution of SSL to evaluate changes in sediment yield in the section "Analysis of Suspended-Sediment Budget."

\section{Water Years 2007-10}

Streamflow for the 4-year study period was compared to the streamflow during the 70 -year period of record to assess whether the study period is representative of long-term streamflow conditions. Three metrics were used to evaluate the amount of streamflow at the Sycamore station (table 4). All three metrics were selected to identify and to evaluate aspects of the streamflow that could result in an unusual amount of suspended sediment in Johnson Creek during the study period. 
Table 4. Streamflow statistics for Johnson Creek at Sycamore, Oregon (station 14211500).

\begin{tabular}{lcccccc}
\hline & \multicolumn{6}{c}{ Streamflow statistics, by water year, in cubic feet per second } \\
\cline { 2 - 7 } & $\begin{array}{c}\text { Average } \\
(\mathbf{1 9 4 1 - 2 0 1 0 )}\end{array}$ & $\mathbf{2 0 0 7}$ & $\mathbf{2 0 0 8}$ & $\mathbf{2 0 0 9}$ & $\mathbf{2 0 1 0}$ & $\begin{array}{c}\text { Average } \\
(\mathbf{2 0 0 7 - 1 0 )}\end{array}$ \\
\hline Annual streamflow & 53.1 & 58.4 & 55.9 & 43.7 & 48.4 & 51.6 \\
Rank (of 70) & & 25 & 28 & 49 & 39 & \\
Percentile & 36 & 41 & 71 & 57 & \\
Annual peak streamflow & 1,270 & 1,030 & 1,430 & 2,430 & 736 & 1,407 \\
Rank (of 70) & & 42 & 22 & 3 & 55 & \\
Percentile & & 61 & 32 & 4 & 80 & \\
Kurtosis of daily mean & 48.1 & 13.3 & 54.6 & 101.3 & 14.1 & 60.6 \\
Rank (of 70) & & 49 & 8 & 2 & 48 & \\
Percentile & & 71 & 12 & 3 & 70 & \\
\hline
\end{tabular}

The first metric evaluated was mean annual streamflow, which is a measure of how much streamflow passed the station in a given water year. During the 4-year study period, the mean annual streamflow was $51.6 \mathrm{ft}^{3} / \mathrm{s}$, which is close to the average value for the 70 -year period of $53.1 \mathrm{ft}^{3} / \mathrm{s}$. The ranks of each water year ranged from 25 (2007) to 49 (2009). Therefore, 24 of the 70 water years on record produced more streamflow than water year 2007, which has the highest mean annual streamflow of the 4-year study period. Conversely, 21 of the 70 years on record produced less annual streamflow than water year 2009, which has the lowest annual streamflow of the 4 water years studied. In summary, the mean annual streamflow during the 4-year study period is representative of mean annual streamflow over the period of record.

The second metric studied was the annual peak streamflow. Based on equations 3 and 4, and the positive correlation between SSC and streamflow, high annual peak streamflow in the Johnson Creek basin would be expected to transport a disproportionately large amount of suspended sediment. Thus, a water year with constant streamflow should transport less suspended sediment than a water year with the same total streamflow, but that also included several large peaks.

Of the 4 water years in this study, three of the annual peaks were unexceptional. Water years 2007, 2008, and 2010 produced peaks that ranked between 22 and 55 out of the 70 years of record. However, the peak annual streamflow of water year 2009 was the third highest on record, lower only than the peak annual streamflows of 1965 and 1997.

The third metric studied was the kurtosis of the daily mean values of streamflow. Traditionally, kurtosis is considered a measure of the "peakedness" of a population (a distribution with a high kurtosis has a pronounced peak near the mean), although there is some debate as to whether it is more of a measure of heavy tails (abundance of extreme events) (Kaplansky, 1945; Ali, 1974; Johnson and others,
1980). Higher kurtosis values indicate that the variance of the distribution is the result of infrequent extreme deviations. Conversely, frequent, smaller deviations would result in lower kurtosis values. For this study, kurtosis can be considered a supplemental metric to the peak annual streamflow. High kurtosis values suggest a water year with more "flashiness," or multiple high peaks, and low kurtosis values suggest smaller and (or) less frequent peaks. It is possible for a given water year to have several moderate peaks, none of which qualify as exceptional. In such an example, the total of many moderate peaks could produce a substantial amount of suspended sediment. However, if these peaks occurred in a water year with relatively little streamflow, and if the peak annual streamflow were near or less than average, the first two metrics used to evaluate streamflow would suggest that the water year might have produced relatively little sediment. In this example, a high kurtosis value resulting from numerous peaks would explain SSLs that were higher than would be expected based on the first two metrics alone.

The kurtosis values of water years 2007 and 2010 were low, with ranks of 49 and 48 out of 70 , respectively. The kurtosis value for water year 2008 was moderately high, ranking 8 out of 70 . This high kurtosis value likely is in part a result of the high streamflows of December 2007 (water year 2008), which were the largest monthly streamflows during the period of study. The water year 2009 kurtosis value was very high, ranking 2nd highest of 70, and lower only than water year 1994. This likely was a result of the large flood in early January, coupled with a series of minor peaks and a relatively low winter base flow.

Together, the three flow metrics evaluated indicate mostly moderate levels of flow during the period of study. The least amount of overall flow of the 4-water-year study was in water year 2009. However, water year 2009 also produced an exceptionally large peak annual streamflow and high kurtosis value. 


\section{Selected Peak Streamflow Events}

Two peak streamflow events during the period of study merit additional discussion. The first is the high peak streamflow of January 2, 2009. On January 1, 2009, 2.53 in. of rain fell at the Holgate rain gage (fig. 1; U.S. Geological Survey, 2011d). This was the most precipitation that fell during a 24-hour period for the period of study. The following day, another 0.79 in. of rain fell. Combined with relatively high streamflow from precipitation falling during the previous 8 days (2.92 in. total), the result was the third-largest flood in the 70-year history of the Sycamore station. About 37 percent of the streamflow from water year 2009 occurred during the 20-day period from December 25, 2008 to January 13, 2009.

The other peak streamflow occurred in June 2010. Sustained rains through late May and early June resulted in a rare June peak instantaneous streamflow of $501 \mathrm{ft}^{3} / \mathrm{s}$ on June 4. Mean daily streamflows were $260,167,360$, and $175 \mathrm{ft}^{3} / \mathrm{s}$ on June 2, 3, 4, and 5, respectively. The June 4, 2010, mean daily streamflow was the second highest of any June value in 70 years of record, second only to June 21, 1984. The June 2,3 , and 5 mean daily streamflows were the 4th-highest, 10th-highest, and 8th-highest streamflows, respectively. The highest streamflow of any June in history was June 2010 as a whole, at 4,640 acre-ft, surpassing the second-highest June streamflow of 3,780 acre-ft in 1984.

\section{Spatial Distribution of Streamflow}

Evaluation of the spatial and temporal distribution of streamflow originating upstream of the Gresham station provides a useful context for comparison with the SSL budget and drainage areas upstream of the Gresham and Milwaukie stations. In a uniform watershed with equal characteristics (such as topography, soils, and precipitation distribution), the proportion of streamflow and SSL originating upstream of Gresham would be identical to the proportion of the drainage area that the Gresham station represents relative to the Milwaukie station.

The proportion of monthly streamflow at the Milwaukie station that originates upstream of the Gresham station is computed in table 5 . The proportion has a positive correlation with the total monthly streamflow. During the five wettest months of the year, November through March, about one-half of the streamflow at the Milwaukie station originates upstream of the Gresham station (table 5). For reference, the drainage area upstream of the Gresham station represents 29 percent of the total drainage area at the Milwaukie station. As streamflow decreases, the proportion of streamflow originating upstream of Gresham also decreases and reaches a low of 10 percent in August, the month typically with the least amount of streamflow in the year. The decrease in streamflow upstream from Gresham relative to overall streamflow in Johnson Creek is a result of Crystal Springs Creek, which flows into Johnson Creek between Sycamore and Milwaukie and provides a relatively stable source of base flow throughout the year (Lee and Snyder, 2009). Annually, 45.4 percent of the streamflow at the Milwaukie station from water year 2007 to 2010 originated upstream of the Gresham station.

\section{Analysis of Suspended-Sediment Budget}

Annual and monthly SSL were computed for the Gresham and Milwaukie stations for water years 2007-10 (table 6, figs. 6 and 7). The SSL values were evaluated in several different ways. To compare SSL output at the two stations, monthly and annual SSL were divided by their respective drainage areas, which results in the suspended-sediment yield (SSY). SSY is a method of standardizing results, which makes for easier comparison between watersheds of differing sizes. The annual SSL and SSY were evaluated along with the findings from the streamflow analysis. The annual and monthly proportions of SSL at the Milwaukie station originating upstream of the Gresham station were also computed and evaluated in relation to the proportion of streamflow originating upstream of the Gresham station.

Table 5. Ratio of monthly streamflow for the Gresham and Milwaukie gaging stations, Johnson Creek basin, Oregon, water years 2007-10.

[For reference, the drainage area of the Gresham gage is approximately 29 percent of the Milwaukie gage. Station reference: Complete station names are shown in table 1 and locations are shown in figure 1]

\begin{tabular}{lc}
\hline Month & $\begin{array}{c}\text { Streamflow (Gresham) / } \\
\text { discharge (Milwaukie) } \\
\text { (percent) }\end{array}$ \\
\hline October & 29.0 \\
November & 52.0 \\
December & 50.4 \\
January & 50.5 \\
February & 47.8 \\
March & 50.5 \\
April & 43.9 \\
May & 39.2 \\
June & 36.3 \\
July & 10.9 \\
August & 10.3 \\
September & 12.8 \\
Annual & 45.4 \\
\hline
\end{tabular}


Table 6. Annual and monthly suspended-sediment load for the Gresham and Milwaukie gaging stations, Johnson Creek basin, Oregon, water years 2007-10.

[Station reference: Complete station names are shown in table 1 and locations are shown in figure 1. SSL (suspended-sediment load, in tons): All values rounded to 3 significant figures, which results in the percentage of annual total values not computing precisely]

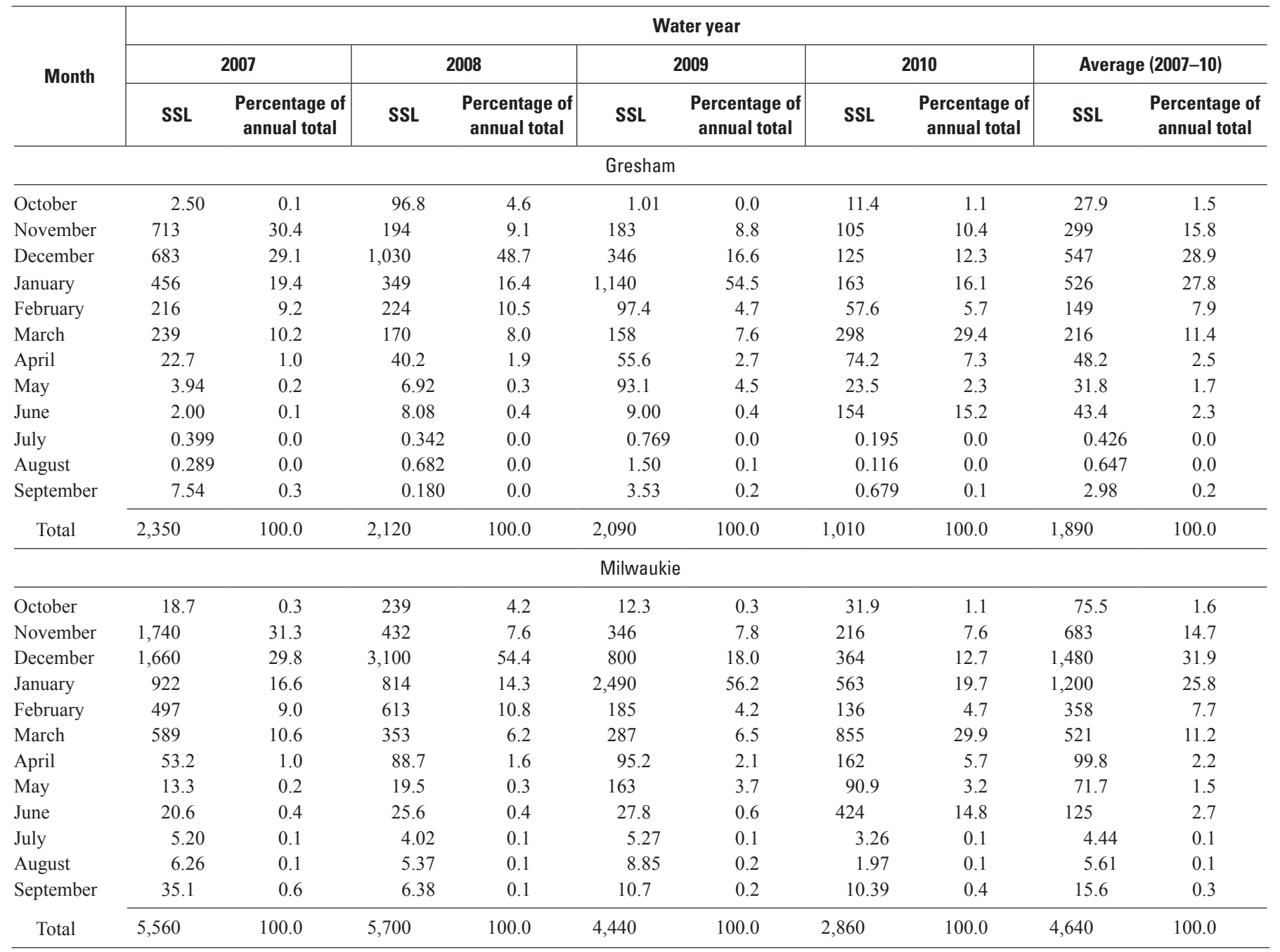




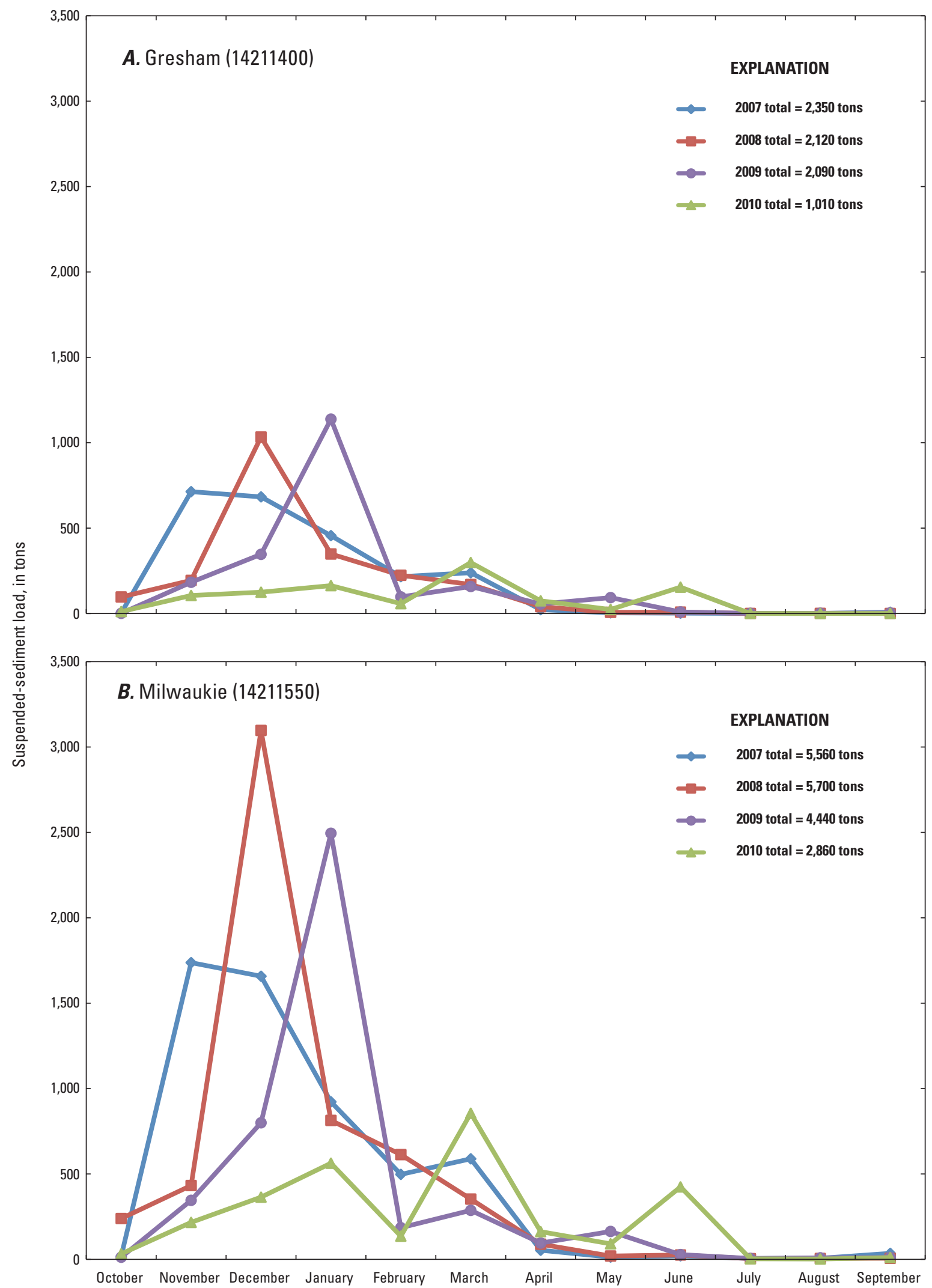

Figure 6. Computed monthly suspended-sediment loads for the $(A)$ Gresham (14211400) and (B) Milwaukie (14211550) streamflow-gaging stations, Johnson Creek basin, Oregon, water years 2007-10. 


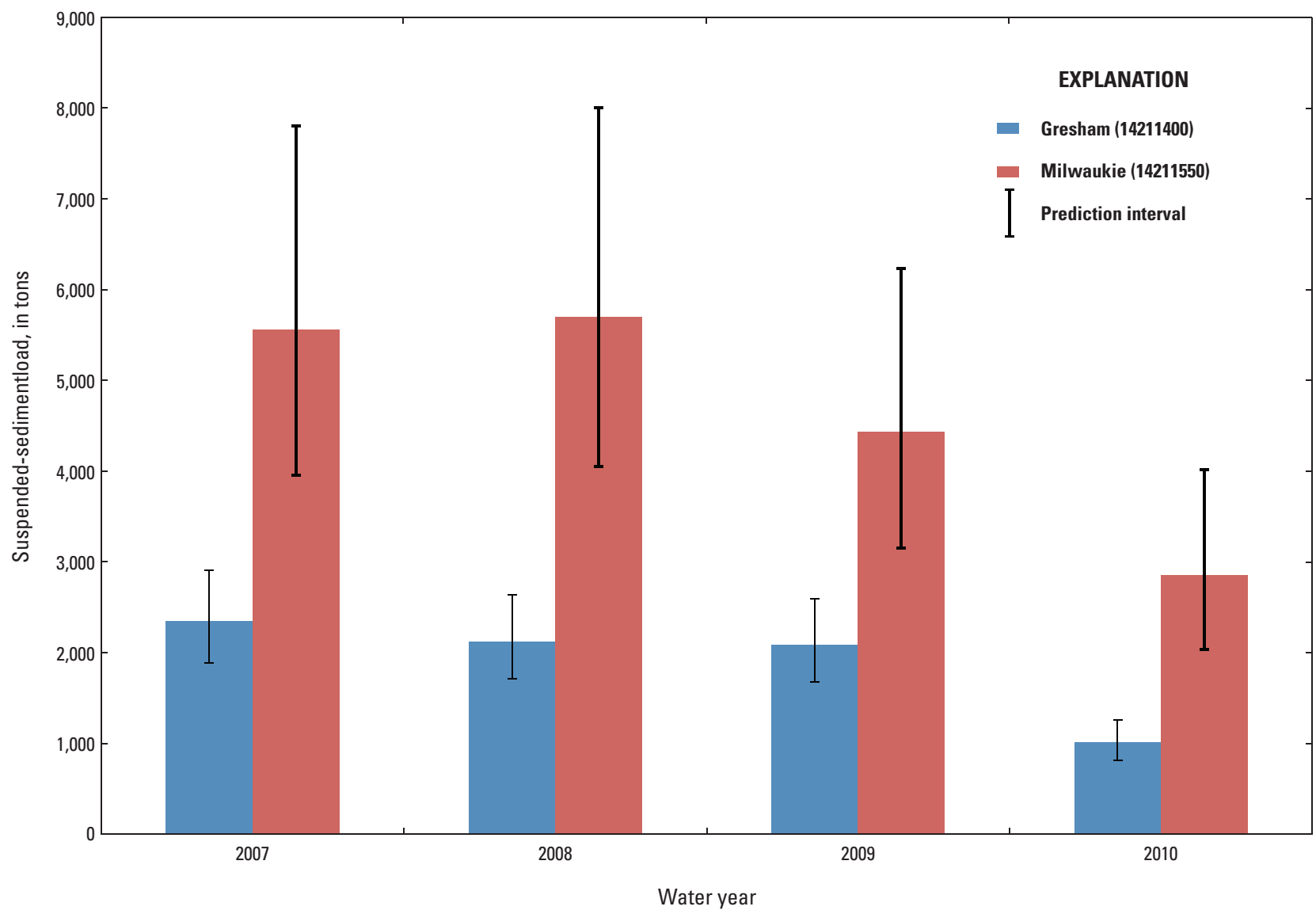

Figure 7. Computed annual suspended-sediment loads for the Gresham (14211400) and Milwaukie (14211550) streamflow-gaging stations, Johnson Creek basin, Oregon, water years 2007-10.

\section{Annual Suspended-Sediment Loads and Yields}

The computed average annual SSL was 1,890 tons at Gresham and 4,640 tons at Milwaukie. These equate to average annual sediment yields of 123 and 87.2 tons $/ \mathrm{mi}^{2}$ at Gresham and Milwaukie, respectively (table 7). The amount of SSL for each individual water year can be explained at least in part by the previously evaluated streamflow metrics.

On the basis of total annual streamflow, water year 2007 was the wettest of the 4 years (table 4 ). The late autumn of 2007 was especially wet; November and December produced the second- and third-highest monthly streamflow during the period of study. At the Gresham station, this translated to the highest computed annual suspended-sediment load of the 4 years, 2,350 tons, and annual yield, 153 tons $/ \mathrm{mi}^{2}$ (tables 6 and 7). For the Milwaukie station, the 2007 SSL was slightly less than the water year 2008 total. The annual SSL for the Gresham and Milwaukie stations in water year 2007 were 124 and 120 percent of the water year 2007-10 averages, respectively.
Water year 2008 was drier than 2007 on the basis of total annual flow at the Sycamore streamflow-gaging station. However, water year 2008 contained a higher peak annual streamflow than $2007\left(1,430 \mathrm{ft}^{3} / \mathrm{s}\right.$ compared with 1,030 ft $\left.3 / \mathrm{s}\right)$, and the kurtosis of the daily mean streamflow for the water year was the eighth-highest on record (table 4), which suggest more SSL. Additionally, December 2007 (water year 2008) was the wettest month during the period of study. This resulted in total SSL values that were close to 2007 values. The annual SSL for the Gresham and Milwaukie stations in water year 2008 were 112 and 123 percent of the water year 2007-10 averages, respectively.

Water year 2009 was the driest of the 4 water years (table 4). However, it also included the third-largest peak annual streamflow on record and the second-highest kurtosis value, suggesting a higher annual total of SSL than what would be expected based on annual streamflow alone. The flashiness of water year 2009 seemed to have more of an effect at Gresham than at Milwaukie. About 2,090 tons of suspended sediment passed the Gresham station in water year 2009 (table 6), which equates to an annual yield of $136 \mathrm{tons} / \mathrm{mi}^{2}$. 
The annual total of suspended sediment at Milwaukie was computed as 4,440 tons, which is a yield of 83 tons $/ \mathrm{mi}^{2}$. These totals represent 110 percent and 96 percent of the 2007-10 averages at the Gresham and Milwaukie stations, respectively.

Of the 4 water years studied, 2010 was closest to the median of the 70 years of average annual streamflows. However, the timing of the streamflow was atypical, with a smaller proportion of streamflow occurring in the winter, and a greater-than-usual proportion occurring in late spring and early summer. The average annual flow of $48.4 \mathrm{ft}^{3} / \mathrm{s}$ at Sycamore ranked 39th out of 70 years of record (table 4). Both the peak annual streamflow and kurtosis values were relatively low, ranking 55th and 48th, respectively. Due in part to the lack of significant high peak streamflows, the 2010 annual suspended-sediment loads were the lowest of the 4 years at the Gresham and Milwaukie stations. The computed annual totals of SSL at Gresham and Milwaukie were 1,010 and 2,860 tons, respectively. The annual yields for water year 2010 at the Gresham and Milwaukie stations were 66.0 and 53.8 tons $/ \mathrm{mi}^{2}$, respectively. These totals represent 54 and 62 percent of the 2007-10 averages at the Gresham and Milwaukie stations, respectively.

Table 7. Monthly and average annual suspended-sediment yield for the Gresham and Milwaukie gaging stations, Johnson Creek basin, Oregon, water years 2007-10.

[Station reference: Complete station names are shown in table 1 and locations are shown in figure 1. All suspended-sediment load values rounded to 3 significant figures, which results in the percentage of annual total values not computing precisely]

\begin{tabular}{|c|c|c|c|c|c|}
\hline \multirow{3}{*}{ Month } & \multicolumn{5}{|c|}{ Suspended-sediment yield, in tons per square mile } \\
\hline & \multicolumn{5}{|c|}{ Water year } \\
\hline & 2007 & 2008 & 2009 & 2010 & $\begin{array}{c}\text { Average } \\
(2007-10)\end{array}$ \\
\hline \multicolumn{6}{|c|}{ Gresham } \\
\hline October & 0.16 & 6.3 & 0.07 & 0.74 & 1.8 \\
\hline November & 46 & 13 & 12 & 6.9 & 19 \\
\hline December & 44 & 67 & 23 & 8.1 & 36 \\
\hline January & 30 & 23 & 74 & 11 & 34 \\
\hline February & 14 & 15 & 6.3 & 3.7 & 10 \\
\hline March & 16 & 11 & 10 & 19 & 14 \\
\hline April & 1.5 & 2.6 & 3.6 & 4.8 & 3.1 \\
\hline May & 0.26 & 0.45 & 6.1 & 1.5 & 2.1 \\
\hline June & 0.13 & 0.53 & 0.59 & 10 & 2.8 \\
\hline July & 0.03 & 0.02 & 0.05 & 0.01 & 0.028 \\
\hline August & 0.02 & 0.04 & 0.10 & 0.01 & 0.042 \\
\hline September & 0.49 & 0.01 & 0.23 & 0.04 & 0.19 \\
\hline Total & 153 & 138 & 136 & 66.0 & 123 \\
\hline \multicolumn{6}{|c|}{ Milwaukie } \\
\hline October & 0.35 & 4.5 & 0.23 & 0.60 & 1.4 \\
\hline November & 33 & 8.1 & 6.5 & 4.1 & 13 \\
\hline December & 31 & 58 & 15 & 6.8 & 28 \\
\hline January & 17 & 15 & 47 & 11 & 23 \\
\hline February & 9.4 & 12 & 3.5 & 2.5 & 7 \\
\hline March & 11 & 6.6 & 5.4 & 16 & 10 \\
\hline April & 1.0 & 1.7 & 1.8 & 3.0 & 1.9 \\
\hline May & 0.25 & 0.37 & 3.1 & 1.7 & 1.3 \\
\hline June & 0.39 & 0.48 & 0.52 & 7.98 & 2.3 \\
\hline July & 0.10 & 0.08 & 0.10 & 0.06 & 0.08 \\
\hline August & 0.12 & 0.10 & 0.17 & 0.04 & 0.11 \\
\hline September & 0.66 & 0.12 & 0.20 & 0.20 & 0.29 \\
\hline Total & 104 & 107 & 83.4 & 53.8 & 87.2 \\
\hline
\end{tabular}




\section{Seasonal Timing of Suspended-Sediment Loads}

Monthly SSL totals were investigated to evaluate the timing of SSL transport in the watershed. At the Gresham station, an average of 73 percent of the annual SSL was transported during the 3 months of November-January. On average, only 8 percent of the SSL was transported during the 7 months of April-October. The Milwaukie station produced similar results (72 and 9 percent, respectively).

Large peak streamflows account for a disproportionate amount of annual SSL. The January 2009 monthly streamflow produced more than 54 percent of the annual suspendedsediment budget for both stations. The highest proportion of annual SSL totals for either station was in January 2009. For the Gresham station, the highest monthly SSL value was in January 2009, even though only the fourth-highest streamflow for the study period was measured there during that month. The second-highest monthly SSL value at the Milwaukie station was in January 2009. The highest monthly streamflow for both stations was in December 2008 and produced the highest monthly SSL during the period of study at the Milwaukie station, which was about 25 percent higher than the January 2009 SSL value. The second-highest SSL for the Gresham station was in December 2008. This discrepancy suggests that the Gresham station is more responsive to large peak streamflow events (such as January 2009) than the Milwaukie station.

The 2010 June peak streamflow was unusual because high flows typically do not occur in the watershed during June. June 2010 was one of the periods without turbidity data, and SSL values for the month are estimated. Although the estimated SSL totals for June 2010 were not large compared to those in winter or early spring, they were 17 and 13 times greater than the SSL totals for any other summer month (June-September) during the period of study for the Gresham and Milwaukie stations, respectively.

The SSL totals during the winter storms demonstrate that most SSL was transported during large streamflow events. The extent to which the highest streamflows produce SSL is quantified in table 8. A nonexceedance level represents the percentage of time that a specific streamflow of SSL level is not exceeded. For example, the 0.9 -nonexceedance level at Gresham is $92.3 \mathrm{ft}^{3} / \mathrm{s}$. Throughout the 12 years of streamflow data collected at the Gresham gaging station, 10 percent of the time, the streamflow rate exceeded $92.3 \mathrm{ft}^{3} / \mathrm{s}$, and 90 percent of the time, the streamflow rate was less than that value. A nonexceedance level of 0.99 is rarely exceeded (an average of one time for every 100 units of measurement), whereas a nonexceedance level of 0.5 indicates that value is exceeded one-half of the time (median).

In Johnson Creek, the highest 1 percent of streamflow (nonexceedance level of 0.99) carried about one-half the total SSL during the 4 years of study at the Gresham and Milwaukie stations. Similarly, less than 1 percent of SSL is transported at streamflows equal to or less than the median streamflow (nonexceedance of 0.5 ) during the 4 years of study at both stations.
Figure 8 expands on table 8 but is not directly comparable. The cumulative amount of SSL equal to or greater than specific nonexceedance values of streamflow is shown in table 8. Alternatively, the nonexceedance values of SSL are compared with cumulative values of SSL in figure 8. This comparison provides a means of evaluating the degree of skewness in the distributions of SSL and streamflow. If the streamflow for Gresham were constant throughout the year, the nonexceedance values on the $\mathrm{x}$-axis would be equal to 100 minus the cumulative values of the y-axis. As the line moves farther to the right, more skew is apparent, indicating that a few high values of streamflow or SSL account for a greater percentage of the cumulative totals. For example, in figure $8 \mathrm{~A}$, point $\mathrm{A}$ shows that the top 1 percent of streamflows (the total of all streamflows exceeding the 99th-percentile) accounts for 14 percent of all cumulative streamflow over the 4 years of study at Gresham. Similarly, point B shows that the top 1 percent of all SSL accounts for 53 percent of cumulative SSL during the 4 years of study.

The distribution of SSL is more heavily skewed than streamflow at the two stations (fig. 8). That is, SSL plots higher on the graph, indicating that the highest SSL nonexceedance values account for a much greater share of cumulative SSL than streamflow. This indicates that most sediment moves through the watershed during storm events, and especially during the heaviest storm events.

Table 8. Streamflow and suspended-sediment load statistics for the Gresham and Milwaukie gaging stations, Johnson Creek basin, Oregon, water years 2007-10.

[Station reference: Complete station names are shown in table 1 and locations are shown in figure $1 . \mathrm{ft}^{3} / \mathrm{s}$, cubic foot per second]

\begin{tabular}{|c|c|c|c|}
\hline \multirow{2}{*}{$\begin{array}{c}\text { Nonexceedance } \\
\text { level }\end{array}$} & \multirow{2}{*}{$\begin{array}{c}\text { Streamflow } \\
\left(\mathrm{ft}^{3} / \mathrm{s}\right)\end{array}$} & \multicolumn{2}{|c|}{ Percentage at or above streamflow } \\
\hline & & Streamflow & $\begin{array}{l}\text { Suspended- } \\
\text { sediment load }\end{array}$ \\
\hline \multicolumn{4}{|c|}{ Gresham } \\
\hline 0.99 & 265 & 14.0 & 50.2 \\
\hline 0.95 & 134 & 34.8 & 76.3 \\
\hline 0.9 & 92.3 & 50.8 & 86.5 \\
\hline 0.8 & 54.7 & 71.3 & 94.7 \\
\hline 0.7 & 31.6 & 83.4 & 97.7 \\
\hline 0.6 & 18.9 & 90.7 & 99.3 \\
\hline 0.5 & 11.1 & 94.9 & 99.7 \\
\hline \multicolumn{4}{|c|}{ Milwaukie } \\
\hline 0.99 & 551 & 12.4 & 49.3 \\
\hline 0.95 & 249 & 30.2 & 77.1 \\
\hline 0.9 & 168 & 43.6 & 86.9 \\
\hline 0.8 & 101 & 60.7 & 94.3 \\
\hline 0.7 & 71.0 & 71.8 & 97.1 \\
\hline 0.6 & 51.7 & 79.7 & 98.6 \\
\hline 0.5 & 38.8 & 85.8 & 99.1 \\
\hline
\end{tabular}



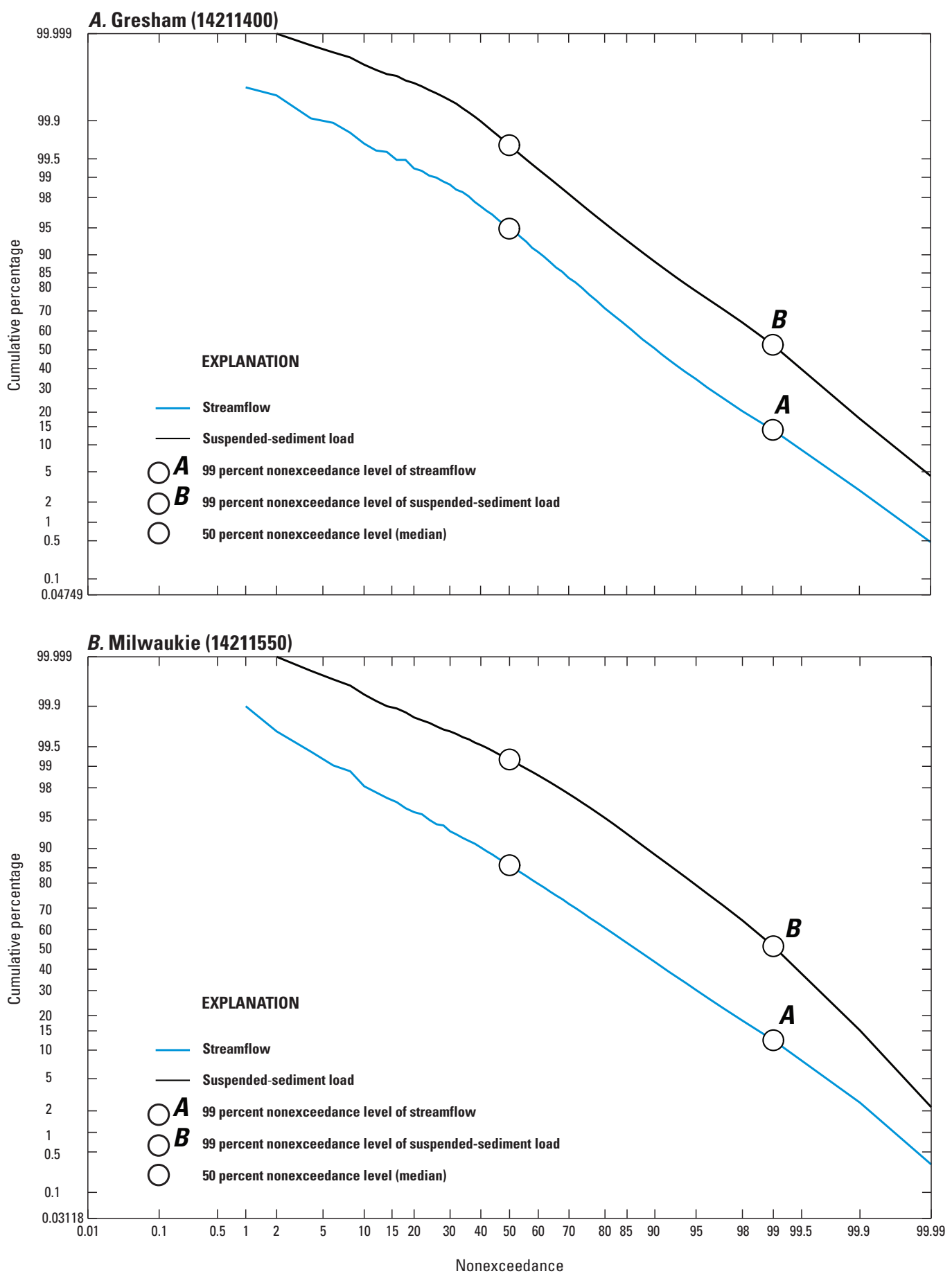

Figure 8. Cumulative distribution of nonexceedance values of continuous streamflow and suspended-sediment load at the $(A)$ Gresham (14211400) and $(B)$ Milwaukie (14211550) streamflow-gaging stations, Johnson Creek basin, Oregon, water years 2007-10. 


\section{Spatial Distribution of Suspended-Sediment Load}

The monthly and annual percentages of SSL originating upstream of the Gresham station were calculated by dividing the monthly and annual SSL totals for the Gresham station by the corresponding monthly and annual SSL totals for the Milwaukie station, and then multiplying each total by 100 (table 9). Some suspended sediment may settle out between the Gresham and Milwaukie stations, especially at low flows with lower velocities. For purposes of this report, it is assumed that most sediment that settles between the two stations is later resuspended by future high streamflows. The possible exception is peak streamflows, which could deposit sediment high on the flood plain where water rarely reaches and vegetative growth could capture sediment.

For the wettest months (November-March), the percentage of SSL originating upstream of the Gresham station ranged from 37.0 percent in December to 43.9 percent in January. With only 4 years of data, this relatively small range could be a result of random variation rather than significant differences between these months.

The percentage of SSL originating upstream of the Gresham station peaked at 48.3 percent in April and reached a low of 9.6 percent in July, the driest month in the region. There is a positive correlation between streamflow at Sycamore and the proportion of Milwaukie SSL originating upstream of the Gresham station (fig. 9). For months when the proportion of SSL that originates upstream of the Gresham station is 25 percent or less, average monthly streamflow at the Sycamore station is always less than $10 \mathrm{ft}^{3} / \mathrm{s}$. Conversely, the proportion of SSL that originates upstream of the Gresham station was at least 30 percent during all months with an average monthly streamflow of $100 \mathrm{ft}^{3} / \mathrm{s}$ or more.

This correlation partially is a result of the tributary Crystal Springs Creek, which enters Johnson Creek between the Sycamore and Milwaukie gaging stations. Streamflow at Crystal Springs Creek is fed predominantly by springs, which, in turn, are closely tied to groundwater levels, resulting in a more constant streamflow than in the rest of the watershed (Lee and Snyder, 2009). As a result of this constant source of streamflow, during low-flow periods, streamflow yield (streamflow divided by drainage area) at the Milwaukie station remains high relative to streamflow yield at the Gresham station. Although both stations typically have low SSCs during low-flow periods (the lowest streamflow months of July and August account for an average of less than 0.2 percent of the overall sediment budget for both stations), the seasonally high proportion of streamflow originating from Crystal Springs Creek results in a lower proportion of overall SSL at the Milwaukie station originating upstream of the Gresham station.

Annual SSL originating upstream of the Gresham station accounted for 40.8 percent of the Milwaukie station totals (table 9). The drainage area upstream of the Gresham station is about 29 percent of the area upstream of the Milwaukie station. These drainage areas are based on topography, and the effective drainage area at the Milwaukie station is smaller than the topographical drainage area of the Milwaukie station because of combined sewer systems, stormwater managed infiltration, storm systems, and other anthropogenic water delivery systems. The annual streamflow at the Gresham station is 45 percent of the annual streamflow at the Milwaukie station for the period of study, or 43 percent if the entire concurrent record of both stations (water years 1999-2010) is considered. These results imply that the amount of SSL originating upstream of the Gresham station is proportional to the amount of streamflow originating upstream of Gresham.

This discrepancy between the percentage of SSL and percentage of drainage area is reflected in the annual yield totals. The average annual SSY of 123 tons $/ \mathrm{mi}^{2}$ at the Gresham station is 141 percent of the average annual SSY at the Milwaukie station, which is 87.2 tons $/ \mathrm{mi}^{2}$ (table 7). For comparison, the annual streamflow yield at Gresham is 139 percent of the annual streamflow yield at Milwaukie (1.99 and $1.44\left(\mathrm{ft}^{3} / \mathrm{s}\right) / \mathrm{mi}^{2}$, respectively). These results suggest that nearly all of the higher sediment yield at the Gresham station can be explained by the higher streamflow yield. This is somewhat surprising because the watershed upstream of Gresham is largely a mix of forest (about one-quarter) and agricultural areas (most of the rest), whereas the area of the watershed between Gresham and Milwaukie is largely urban (79 percent). A comprehensive investigation of the sediment availability of the watershed is beyond the scope of this study, but potential explanations include most suspended sediment originating from near-bank locations, more sediment than expected being produced by urban areas, and (or) the forested area upstream of Gresham capturing more sediment than expected.

Table 9. Monthly and annual percentages of suspended-sediment loads originating upstream of the Gresham gaging station, Johnson Creek basin, Oregon, water years 2007-10.

[Station reference: Complete station names are shown in table 1 and locations are shown in figure 1. For reference, the drainage area of the Gresham gage is approximately 29 percent of Milwaukie. SSL, suspended-sediment load]

\begin{tabular}{lc}
\hline \multicolumn{1}{c}{ Month } & $\begin{array}{c}\text { SSL (Gresham)/ } \\
\text { SSL (Milwaukie) } \\
\text { (percent) }\end{array}$ \\
\hline October & 37.0 \\
November & 43.8 \\
December & 37.0 \\
January & 43.9 \\
February & 41.5 \\
March & 41.5 \\
April & 48.3 \\
May & 44.4 \\
June & 34.8 \\
July & 9.6 \\
August & 11.5 \\
September & 19.1 \\
\hline \multicolumn{1}{c}{ Annual } & 40.8 \\
\hline
\end{tabular}




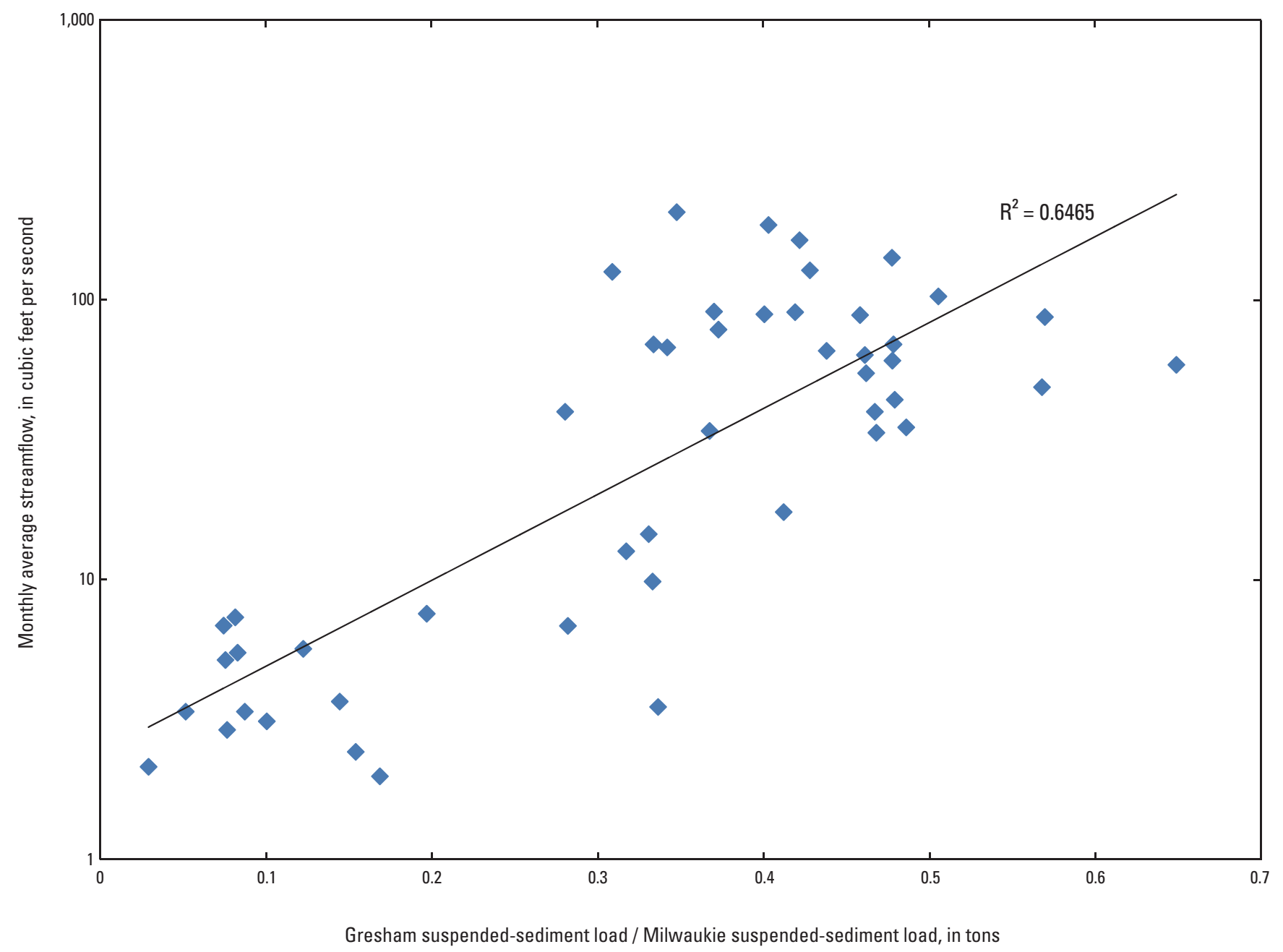

Figure 9. Ratio of monthly suspended-sediment load for the Gresham gaging station to monthly suspended-sediment load for the Milwaukie gaging station, compared to monthly average streamflow at the Sycamore station, Johnson Creek basin, Oregon, water years 2007-10. 


\section{Potential Errors and Uncertainties}

One of the most readily identifiable potential sources of error is the extrapolation of the turbidity-and-streamflowto-SSC relation. The method of calculating SSL proposed by Rasmussen and others (2009) and previous investigations assumes a linear relation between logarithmic values of SSC and turbidity and (or) streamflow. SSC values extrapolated beyond the range of those used in the regression model development assume that the linear relation between SSC and turbidity and streamflow extends outside that range. The farther that SSC values deviate from this range the less reliable this assumption and the more uncertain are the SSC values.

For the Gresham station, SSC values used in the model ranged from 39 to $288 \mathrm{mg} / \mathrm{L}$. Eighteen percent of the total SSL computed was derived from SSC values below that range and 20 percent of the total SSL computed was derived from $\mathrm{SSC}$ values above that range. For the Milwaukie station, SSC values used for the model ranged from 47 to $378 \mathrm{mg} / \mathrm{L}$. Seventeen percent of the total SSL computed was derived from SSC values below that range, whereas 1 percent of the total SSL was derived from SSC values above that range.

As with most physical science studies, there is no physical rationale for this assumption of linearity. Linear relations are assumed primarily for ease of computation and to allow for the calculation of prediction intervals and other error analyses.

Other potential sources of error include random error in any of the SSC, streamflow, or turbidity measurements, and uncertainties in the estimated time series for turbidity and streamflow (which represent 4 percent and 7 percent of the SSL at the Gresham and Milwaukie stations, respectively). Temporal physical factors also can affect the SSC-turbidity relation, including a change in the shape, size, or color of particles in the water (Anderson, 2005) or the presence of microorganisms such as phytoplankton (Rasmussen and others, 2009). These factors could affect the turbidity without affecting SSC, thus altering the relation between the two parameters.

\section{Potential for Future Studies}

Refinement of the SSC-to-turbidity-and-streamflow relations at the Gresham and Milwaukie stations will aid future calculations of SSL. Streamflow, SSC, and turbidity data are scheduled to be collected through at least water year 2012. The additional 2 years of collection can be used to refine the current regression models (especially at the highest streamflows, when most sediment is transported) and to investigate possible temporal changes in the SSC-to-turbidityand-streamflow relation.

Additionally, continuous streamflow and turbidity data, and periodic SSC data are being collected in Kelley Creek, which is the largest tributary of Johnson Creek. An
SSC-to-turbidity or SSC-to-turbidity-and-streamflow relation at Kelley Creek will provide a useful tool for quantifying how much suspended sediment originates from this area of the watershed. Kelley Creek enters Johnson Creek just upstream of the Sycamore gaging station and represents 9 percent of the total drainage area of the watershed.

To evaluate the source of sediment upstream of the Gresham station, periodic measurements of streamflow, turbidity, and SSC are being collected at two additional sites on the main stem of Johnson Creek and on another of the largest tributaries (Sunshine Creek). All three sites (not shown in fig. 1) are upstream of the Gresham station. Although these locations will not have a continuous time series of streamflow or turbidity needed to compute a daily SSL time series, comparing these measurements to values obtained at the continuous stations will provide insight into quantifying where, when, and how much suspended sediment originates in the upstream area of the watershed.

With measurements of continuous turbidity and streamflow at these three stations, monthly SSL could be computed to enhance the understanding of the suspendedsediment budget in the watershed. Installation of a turbidity probe and (or) stage sensor (along with streamflow measurements over the range of the hydrograph) at any of the three upstream sites would allow for the calculation of annual turbidity and (or) streamflow time series. Provided an adequate SSC-to-turbidity-and-streamflow relation exists, subsequent SSL time series could be computed. This calculation would result in a more precise and accurate quantification of the SSL upstream from any of these stations, rather than general inferences made from a limited number of periodic measurements.

Other measurement stations also might prove beneficial. The other substantial tributaries (North Fork Johnson Creek, Badger Creek, Sunshine Creek, Hogan Creek, and Butler Creek) account for almost 20 percent of the total drainage area of the watershed. Even periodic measurements of SSC, turbidity, and streamflow, could provide general inferences regarding the timing and sourcing of suspended sediment.

SSC samples or turbidity measurements also could be taken at or near current or future restoration sites. Such data could provide an understanding of the effects of current or future measures to reduce suspended sediment in the stream. Evaluating and quantifying the effects of such ongoing work may help guide choices in future restoration work within the Johnson Creek watershed.

The relation between SSC and acoustic Doppler current profiler (ADCP) data in estuary or large riverine environments has been investigated in recent studies (Thevenot and Kraus, 1993; Topping and others, 2006; Wood and Gartner, 2010). The collection of acoustic Doppler backscatter data as surrogates for SSC has several potential advantages over the use of a turbidity probe. When deployed in a side-looking position, ADCPs collect data in a conic beam rather than at an individual point, and thus are able to better represent suspended sediment in stream cross sections that are not 
always well mixed than methods that use a point source. ADCPs are less prone to biological fouling, and as such may require less service time and fewer resources to maintain. If a multifrequency ADCP, or two ADCPs of different frequency, are deployed, sediment size can be evaluated.

Pesticide concentration in the Johnson Creek basin is highly correlated with SSL (Tanner and Lee, 2004). Deployment of a semipermeable membrane device (Alvarez, 2010) at either the Gresham station or the Milwaukie station could be used to estimate levels of dissolved lipophilic toxic chemicals, such as the pesticide DDT, that accumulate in aquatic organisms in Johnson Creek, and often at levels less than detection limits using conventional water-sampling techniques. Provided there is a reliable relation between SSL and lipophilic toxic chemicals, a continued collection of SSL data could provide valuable insight into pesticide loading in the watershed, and could be compared with previous work in Johnson Creek (McCarthy and Gale, 1999).

Similarly, a significant percentage of SSL (59 percent) appears to originate downstream of the Gresham station, an area of the drainage basin that includes more industrial and urban areas than the area upstream of the Gresham station. Sediment originating in the downstream areas of the watershed might contain a different suite of contaminants than sediment originating upstream in more rural areas. A contaminant study of the lower watershed would help identify potential areas of concern, such as trace elements or hydrocarbons.

\section{Summary and Conclusions}

The U.S. Geological Survey investigated the sources and transport of suspended sediment in the Johnson Creek basin, Oregon, during water years 2007-10, in cooperation with the cities of Damascus, Gresham, Happy Valley, Milwaukie; and Portland; Clackamas County Water Environment Services; Multnomah County; and the East Multnomah Soil and Water Conservation District. Suspended-sediment loads are used by these cooperators, as well as other agencies and parties, as an indicator of the health of the watershed. If specific locations are determined responsible for mobilization of suspended sediment, they can be targeted for future remediation efforts. Similarly, if specific months or seasons are responsible for a disproportionate amount of suspended sediment, greater effort can be undertaken to control erosion during those periods of time. Watershed wide sediment issues likely would warrant more systemic changes in management practices.

Gaging stations at Gresham and Milwaukie provided continuous streamflow and turbidity data. A regression model was created for each station relating suspended-sediment concentration to streamflow and turbidity. These models were used to compute continuous suspended-sediment concentration records and subsequent suspended-sediment loads at both gaging stations. Suspended-sediment loads were evaluated to determine the timing and spatial distribution of suspended sediment transport within the watershed.

Annual streamflow for the 4 water years encompassing the study period was relatively typical of the average for the 1941-2010 period of record; therefore, the amount of suspended sediment computed at the Gresham and Milwaukie stations should be a reasonable indicator of near-average conditions. Annual suspended-sediment loads for the 4-year study period averaged 1,890 and 4,640 tons for the Gresham and Milwaukie stations, respectively. Because there are no major tributaries of Johnson Creek between the Milwaukie station and the confluence with the Willamette River, the Milwaukie station value provides a measure of sediment loading from Johnson Creek to the Willamette River.

During the study, almost 75 percent of the suspendedsediment load originated during November-January for both stations. Conversely, less than 10 percent of the suspendedsediment load originated during April-October for both stations.

For the wettest months (November-May), when most suspended sediment is transported in Johnson Creek, 40 percent of suspended sediment originates upstream of the Gresham station. The topographical drainage area upstream of the Gresham station is about 30 percent of the size of the topographical drainage area upstream of the Milwaukie station. However, the annual streamflow at the Gresham station is about 40 percent of streamflow at the Milwaukie station, so the amount of suspended sediment originating upstream of the Gresham station does not appear to be disproportionate.

The average annual suspended-sediment yields at the Gresham and Milwaukie stations during the study period were 123 and 87.2 tons per square mile, respectively. The annual streamflow yields at the Gresham and Milwaukie stations were 1.99 and 1.44 cubic feet per second per mile, respectively. The annual ratios of Gresham to Milwaukie for suspendedsediment and streamflow are nearly equal, suggesting that on an annual basis, the increased sediment productivity at the Gresham station primarily is the result of higher streamflow yield.

\section{Acknowledgments}

The authors acknowledge the cities of Damascus, Gresham, Happy Valley, Milwaukie, and Portland, Clackamas County Water Environment Services; Multnomah County; and the East Multnomah Soil and Water Conservation District for the cooperative funding that made this study possible. We also thank U.S. Geological Survey Oregon Water Science Center personnel, including Karl Lee, Curt Hughes, Melanie North, Stewart Rounds, and Daniel Snyder, who contributed either directly or indirectly to the products cited in this report. Finally, we acknowledge and thank the reviewers whose comments and suggestions greatly improved this report. 


\section{References Cited}

Ali, M.M., 1974, Stochastic ordering and kurtosis measure: Journal of the American Statistical Association, v. 69, p. 543-545.

Alvarez, D.A., 2010, Guidelines for the use of the semipermeable membrane device (SPMD) and the polar organic chemical integrative sampler (POCIS) in environmental monitoring studies: U.S. Geological Survey, Techniques and Methods chap. 4 of sec. D, book 1, 28 p. (Also available at http://pubs.er.usgs.gov/publication/ tm1D4.)

Anderson, C.W., Rinella, F.A., and Rounds, S.A., 1996, Occurrence of selected trace elements and organic compounds and their relation to land use in the Willamette River basin, Oregon, 1992-94: U.S. Geological Survey Water-Resources Investigations Report 96-4234, 68 p. (Also available at http://pubs.er.usgs.gov/usgspubs/wri/ wri964234.)

Anderson, C.W., 2005, Turbidity: U.S. Geological Survey Techniques of Water-Resources Investigations, book 9, chap. A6.7, 55 p. (Also available at http://pubs.er.usgs.gov/ publication/twri09A6.7.)

Angino, E.E., and O'Brien, W.J., 1968, Effects of suspended material on water quality, in Proceedings of Symposium on Geochemistry, Precipitation, Evaporation, Soil Moisture, Hydrometry, General Assembly of Bern, SeptemberOctober 1967: International Association of Science Hydrology, no. 78, p. 120-128.

ASTM International, 2007, D4410, in terminology for fluvial sediment, annual book of standards, water and environmental technology: West Conshohocken, Pa., ASTM International, $7 \mathrm{p}$.

Bragg, H.M., Sobieszczyk, Steven, Uhrich, M.A., and Piatt, D.R., 2007, Suspended-sediment loads and yields in the North Santiam River Basin, Oregon, water years 19992004: U.S. Geological Survey Scientific Investigations Report 2007-5187, 26 p. (Also available at http://pubs. er.usgs.gov/publication/sir20075187.)
Bragg, H.M., and Uhrich, M.A., 2010, Suspended-sediment budget for the North Santiam River basin, Oregon, water years 2005-08: U.S. Geological Survey Scientific Investigations Report 2010-5038, 26 p. (Also available at http://pubs.er.usgs.gov/publication/sir20105038.)

Duan, N., 1983, Smearing estimate-A nonparametric retransformation method: Journal of the American Statistical Association, v. 78, no. 383, p. 605-610.

Edwards, T.K., 1992, Water quality and flow data for the Johnson Creek basin, Oregon, April 1988 to January 1990: U.S. Geological Survey Open-File Report 92-73, 29 p. (Also available at http://pubs.er.usgs.gov/publication/ ofr9273.)

Edwards, T.K., 1994, Assessment of surface-water quality and water-quality control alternatives, Johnson Creek basin, Oregon: U.S. Geological Survey Water-Resources Investigations Report 93-4090, 50 p. (Also available at http://pubs.er.usgs.gov/publication/wri934090.)

Edwards, T.K., and Curtiss, D.A., 1993, Preliminary evaluation of water-quality conditions of Johnson Creek, Oregon: U.S. Geological Survey Water-Resources Investigations Report 92-4136, 15 p. (Also available at http://pubs.er.usgs.gov/publication/wri924136.)

Edwards, T.K., and Glysson, G.D., 1999, Field methods for measurement of fluvial sediment: U.S. Geological Survey Techniques of Water-Resources Investigations, book 3, chap. C2, 89 p. (Also available at http://pubs.er.usgs.gov/ publication/twri03C2.)

Gilvear, D.J., and Petts, G.E., 1985, Turbidity and suspended solids variations downstream of a regulating reservoir: Earth Surface Processes Landforms, v. 10, no. 4, p. 363-373.

Guy, H.P., 1969, Laboratory theory and methods for sediment analysis: U.S. Geological Survey Techniques of WaterResources Investigations, book 5, chap. C1, 58 p. (Also available at http://pubs.er.usgs.gov/publication/twri05C1.)

Helsel, D.R., and Hirsch, R.M., 2002, Statistical methods in water resources: U.S. Geological Survey Techniques of Water-Resources Investigations, book 4, chap. A3, 510 p. (Also available at http://pubs.er.usgs.gov/publication/ twri04A3.) 
International Organization for Standardization, 1999, Water quality - Determination of turbidity: Geneva, Switzerland, International Organization for Standardization, ISO 7027, $10 \mathrm{p}$.

Jastram, J.D., Moyer, D.L., and Hyer, K.E., 2009, A comparison of turbidity-based and streamflow-based estimates of suspended-sediment concentrations in three Chesapeake Bay tributaries: U.S. Geological Survey Scientific Investigations Report 2009-5165, 37 p. (Also available at http://pubs.er.usgs.gov/publication/ sir20095165.)

Johnson, M.E., Tietjen, G.L., and Beckman, R.J., 1980, A new family of probability distributions with applications to Monte Carlo studies: Journal of the American Statistical Association, v. 75, p. 276-279.

Kaplansky, I., 1945, A common error concerning kurtosis: Journal of the American Statistical Association, v. 40, p. 259-263.

Kennedy, E.J., 1984, Discharge ratings at gaging stations: U.S. Geological Survey Techniques of Water-Resources Investigations, book 3, chap. A10, 59 p. (Also available at http://pubs.er.usgs.gov/publication/twri03A10.)

Lee, K.K., and Snyder, D.T., 2009, Hydrology of the Johnson Creek basin, Oregon: U.S. Geological Survey Scientific Investigations Report 2009-5123, 56 p. (Also available at http://pubs.er.usgs.gov/publication/sir20095123.)

Lietz, A.C., and Debiak, E.A., 2005, Development of rating curve estimators for suspended-sediment concentration and transport in the C-51 canal based on surrogate technology, Palm Beach County, Florida, 2004-05: U.S. Geological Survey Open-File Report 2005-1394, 19 p. (Also available at http://pubs.er.usgs.gov/publication/ofr20051394.).

McCarthy, K.A., and Gale, R.W., 1999, Investigation of the distribution of organochlorine and polycyclic aromatic hydrocarbon compounds in the lower Columbia River using semipermeable membrane devices: U.S. Geological Survey Water-Resources Investigations Report 99-4051, 136 p. (Also available at http://pubs.er.usgs.gov/publication/ wri994051.)
Porterfield, George, 1972, Computation of fluvial-sediment discharge: U.S. Geological Survey Techniques of WaterResources Investigations, book 3, chap. C3, 66 p. (Also available at http://pubs.er.usgs.gov/publication/twri03C3.)

Rantz, S.E., and others, 1982, Measurement and computation of streamflow-Volume 1, measurement of stage and discharge - Volume 2, computation of discharge: U.S. Geological Survey Water Supply Paper 2175, 631 p. (Also available at http://pubs.er.usgs.gov/publication/wsp2175 $\underline{\text { vol1 and http://pubs.er.usgs.gov/publication/wsp2175.) }}$

Rasmussen, P.P., Gray, J.R., Glysson, G.D., and Ziegler, A.C., 2009, Guidelines and procedures for computing time-series suspended-sediment concentrations and loads from in-stream turbidity-sensor and streamflow data: U.S. Geological Survey Techniques and Methods, book 3, chap. C4, 53 p. (Also available at http://pubs.er.usgs.gov/ publication/tm3C4.)

Rasmussen, T.J., Ziegler, A.C., and Rasmussen, P.P., 2005, Estimation of constituent concentrations, densities, loads, and yields on lower Kansas River, northeast Kansas, using regression models and continuous water-quality modeling, January 2000 through December 2003: U.S. Geological Survey Scientific Investigations Report 2005-5165, 117 p. (Also available at http://pubs.er.usgs.gov/publication/ sir20055165.)

Snyder, D.T., 2008, Estimated depth to ground water and configuration of the water table in the Portland, Oregon area: U.S. Geological Survey Scientific Investigations Report 2008-5059, 40 p. (Also available at http://pubs. er.usgs.gov/publication/sir20085059.)

Tanner, D.Q., and Lee, K.K., 2004, Organochlorine pesticides in the Johnson Creek basin, Oregon, 1988-2002: U.S. Geological Survey Scientific Investigations Report 2004-5061, 36 p. (Also available at http://pubs.er.usgs.gov/ publication $/$ sir20045061.)

Thevenot, M.M., and Kraus, N.C., 1993, Comparison of acoustical and optical measurements of suspended material in the Chesapeake Estuary: Gordon and Breach Science Publishers, Journal of Marine Environmental Engineering, v. 1, p. 65-79. 
Topping, D.J., Wright, S.A., Melis, T.S., and Rubin, D.M., 2006, High-resolution monitoring of suspended sediment concentration and grain size in the Colorado River using laser-diffraction instruments and a three frequency acoustic system, in Federal Inter-Agency Sedimentation Conference, 8th, Reno, Nev., April 2-6, 2006, Proceedings: Reno, Nev., Federal Inter-Agency Sedimentation Conference, p. 555-559.

Uhrich, M.A., and Bragg, H.M., 2003, Monitoring in-stream turbidity to estimate continuous suspended-sediment loads and yields and clay-water volumes in the upper North Santiam River basin, Oregon, 1998-2000: U.S. Geological Survey Water-Resources Investigations Report 2003-4098, $43 \mathrm{p}$. (Also available at http://pubs.er.usgs.gov/publication/ wri034098.)

U.S. Environmental Protection Agency, 2011, National summary of state information-Impaired waters listed by state: U.S. Environmental Protection Agency web site, accessed July 10, 2012, at http://iaspub.epa.gov/waters10/ attains_nation_cy.control?p report type $=\mathrm{T} \#$ causes 303d.

U.S. Geological Survey, 2011a, StreamStats - Oregon: U.S. Geological Survey database, accessed July 10, 2012, at http://water.usgs.gov/osw/streamstats/oregon.html.
U.S. Geological Survey, 2011b, USGS water data for Oregon: U.S. Geological Survey data base, accessed July 10, 2012, at http://waterdata.usgs.gov/or/nwis.

U.S. Geological Survey, 2011c, Johnson Creek basin hydrologic monitoring: U.S. Geological Survey Oregon Water Science Center web site, accessed July 10, 2012, at http://or.water.usgs.gov/proj/or175/index.html.

U.S. Geological Survey, 2011d, Holgate rain gageProvisional, uncorrected raw data from the City of Portland HYDRA Network: U.S. Geological Survey Oregon Water Science Center web site, accessed July 10, 2012, at http:// or.water.usgs.gov/non-usgs/bes/holgate.rain.

Walling, D.E., 1977, Assessing the accuracy of suspended sediment rating curves for a small basin: Water Resources Research, v. 13, p. 531-538.

Wood, T.M., and Gartner, J.W., 2010, Use of acoustic backscatter and vertical velocity to estimate concentration and dynamics of suspended solids in Upper Klamath Lake, south-central Oregon-Implications for A phanizomenon flos-aquae: U.S. Geological Survey Scientific Investigations Report 2010-5203, 20 p. (Also available at http://pubs. er.usgs.gov/publication/sir20105203.) 


\section{Appendix A. Model-Calibration Data Set for Johnson Creek at Regner Road at Gresham, Oregon, January 2006-January 2009}

Appendix A. Model-calibration data set for Johnson Creek at Regner Road at Gresham, Oregon, January 2006-January 2009.

\begin{tabular}{|c|c|c|c|c|}
\hline Date & $\begin{array}{c}\text { Turbidity from } \\
\text { fixed-location } \\
\text { sensor } \\
\text { (Formazin } \\
\text { Nephelometric Units) }\end{array}$ & $\begin{array}{l}\text { Streamflow } \\
\text { (cubic feet } \\
\text { per second) }\end{array}$ & $\begin{array}{l}\text { Suspended- } \\
\text { sediment } \\
\text { concentration } \\
\text { (milligrams } \\
\text { per liter) }\end{array}$ & $\begin{array}{l}\text { Percentage of } \\
\text { suspended- } \\
\text { sediment } \\
\text { finer than } \\
62 \text { micrometers }\end{array}$ \\
\hline \multicolumn{5}{|c|}{2006} \\
\hline January 30 & 125 & 174 & 68 & 97 \\
\hline April 10 & 302 & 99 & 167 & 98 \\
\hline \multirow[t]{3}{*}{ November 6} & 109 & 77 & 49 & 98 \\
\hline & 92.8 & 67 & 39 & 97 \\
\hline & 94 & 96 & 55 & 95 \\
\hline November 7 & 227 & 575 & 216 & 91 \\
\hline November 8 & 81.1 & 147 & 57 & 95 \\
\hline \multicolumn{5}{|c|}{2007} \\
\hline March 12 & 89 & 97 & 63 & 97 \\
\hline December 3 & 171 & 798 & 133 & 92 \\
\hline December 3 & 148 & 753 & 118 & 92 \\
\hline December 24 & 120 & 294 & 76 & 91 \\
\hline \multicolumn{5}{|c|}{2008} \\
\hline December 29 & 181 & 688 & 198 & 92 \\
\hline \multicolumn{5}{|c|}{2009} \\
\hline \multirow[t]{2}{*}{ January 1} & 248 & 848 & 266 & 92 \\
\hline & 252 & 843 & 267 & 94 \\
\hline \multirow[t]{3}{*}{ January 2} & 382 & 1,040 & 288 & 92 \\
\hline & 328 & 927 & 263 & 91 \\
\hline & 203 & 361 & 148 & 88 \\
\hline
\end{tabular}




\section{Appendix B. Model-Calibration Data Set for Johnson Creek at Milwaukie, Oregon, December 2005-January 2009}

Appendix B. Model-calibration data set for Johnson Creek at Milwaukie, Oregon, December 2005-January 2009.

\begin{tabular}{|c|c|c|c|c|}
\hline Date & $\begin{array}{c}\text { Turbidity from } \\
\text { fixed-location } \\
\text { sensor } \\
\text { (Formazin } \\
\text { Nephelometric Units) }\end{array}$ & $\begin{array}{l}\text { Streamflow } \\
\text { (cubic feet } \\
\text { per second) }\end{array}$ & $\begin{array}{l}\text { Suspended- } \\
\text { sediment } \\
\text { concentration } \\
\text { (milligrams } \\
\text { per liter) }\end{array}$ & $\begin{array}{l}\text { Percentage of } \\
\text { suspended- } \\
\text { sediment } \\
\text { finer than } \\
62 \text { micrometers }\end{array}$ \\
\hline \multicolumn{5}{|c|}{2005} \\
\hline December 22 & 170 & 552 & 221 & 96 \\
\hline \multicolumn{5}{|c|}{2006} \\
\hline January 30 & 92 & 507 & 118 & 92 \\
\hline \multirow[t]{2}{*}{ April 10} & 198 & 306 & 304 & 95 \\
\hline & 154 & 274 & 161 & 96 \\
\hline April 15 & 76.3 & 256 & 64 & 95 \\
\hline \multirow[t]{3}{*}{ November 6} & 128 & 172 & 81 & 96 \\
\hline & 120 & 191 & 75 & 96 \\
\hline & 88.5 & 294 & 74 & 93 \\
\hline November 7 & 248 & 966 & 241 & 90 \\
\hline November 08 & 67 & 243 & 47 & 95 \\
\hline \multicolumn{5}{|c|}{2007} \\
\hline December 3 & 188 & 1960 & 223 & 81 \\
\hline \multicolumn{5}{|c|}{2008} \\
\hline January 31 & 255 & 527 & 341 & 94 \\
\hline March 13 & 57.7 & 179 & 61 & 95 \\
\hline March 14 & 155 & 276 & 115 & 96 \\
\hline November 6 & 84.8 & 152 & 100 & 96 \\
\hline December 29 & 161 & 905 & 244 & 89 \\
\hline \multicolumn{5}{|c|}{2009} \\
\hline January 1 & 241 & 1,280 & 378 & 88 \\
\hline \multirow[t]{2}{*}{ January 2} & 318 & 2,040 & 338 & 90 \\
\hline & 324 & 2,050 & 326 & 90 \\
\hline
\end{tabular}




\section{Appendix C. Regression Model Evaluation}

Seven linear regression models were evaluated for the Gresham and Milwaukie stations (table 2). Linear regression analysis requires normality of the resulting error distribution (Ott and Longnecker, 2001). Initially, the raw data sets used in the regression models were heavily skewed (a violation of normality). To minimize skew and to produce an error distribution approaching normality, the values of SSC, streamflow, and turbidity were transformed to base- 10 logarithmic values. Other models were run with square root transformation or no transformation for comparative purposes.

When appropriate, it is beneficial to use the same transformation and parameters for models at multiple stations, which tends to result in more congruent SSL computations between stations. The same basic model structure should be used at both stations unless diagnostic results warranted otherwise.

Models were evaluated on the basis of two criteria:

1. Diagnostic linear regression statistics, including:
a. Adjusted coefficient of determination (Adj $\mathrm{R}^{2}$ )
b. Root-mean-squared error (RMSE)
c. Mean absolute error (MAE)
d. Mean absolute percentage error (MAPE)

2. Evaluation of linear regression model residuals, including:

a. The Jarque-Berra test for normality (JB)

b. The Breusch-Pagan test for heteroscedasticity (BP)

Linear regression diagnostic comparisons are meaningful only if the dependent variable is the same for all models. This assumption is violated when some model variables have been log- or square-root transformed. Therefore, when required, diagnostic values were transformed back into linear space before being evaluated.

\section{Diagnostic Linear Regression Statistics}

The coefficient of determination $\left(\mathrm{R}^{2}\right)$ estimates the proportion of variability explained by the regression model. Similarly, the Adj $\mathrm{R}^{2}$ estimates the proportion of variability explained by the regression model while accounting for the number of explanatory variables. RMSE is an unbiased estimator that quantifies the difference between values implied by an estimator and the true values of the quantity being estimated. MAE is a metric for measuring how far predicted values deviate from true values. MAPE expresses error in generic percentage terms. As regression models approach Adj $\mathrm{R}^{2}$ values of 1.0, the models approach perfect correlation. Similarly, as regression models approach RMSE, MAE, and MAPE values of zero, the models approach perfect estimation (residual values of zero).

For the Gresham station, models using streamflow and turbidity as independent variables had higher Adj $\mathrm{R}^{2}$ values and lower RMSE, MAE, and MAPE values than models using a single independent variable (table 2). For the Milwaukie station, models using only turbidity as an independent variable performed as well as or better than models using both streamflow and turbidity as independent variables. However, the improvement in regression diagnostics gained by using a model with only turbidity as an independent variable at Milwaukie was much smaller than the overall advantage gained by using both independent variables at Gresham. Consequently, if the same basic model structure were to be maintained at both stations, the model using both independent variables would provide better overall results.

\section{Evaluation of Linear Regression Model Residuals}

One of the assumptions of linear regression is that the residual errors are normally distributed. Violations of this assumption compromise the estimation of coefficients and the calculation of prediction intervals. The Jarque-Bera (JB) test for normality (Jarque and Bera, 1980) was used on the residuals of each model. The JB test is a goodness-of-fit test that examines the skewness and kurtosis of a distribution and compares it to a matching normal distribution. The JB test statistic has a chi-squared distribution with two degrees of freedom. The P-values associated with the computed JB test statistic are shown in table 2. Using a significance level of 0.05 , values greater than 0.95 suggest a statistically significant departure from normality in the distribution of residuals for the model. For the Gresham and Milwaukie stations, all models failed to reject the null hypothesis of normally distributed residuals.

Linear regression models assume homoscedasticity (constant variance) of the resulting error distribution. 
Violations of the homoscedasticity assumption can result in inaccurate forecast error and prediction intervals. Violations also can result in too much weight given to a small subset of the data, such as the group of measurements with the largest SSC values. The Breusch-Pagan (BP) test can be used to measure heteroscedasticity in a linear regression model (Breusch and Pagan, 1979). The BP tests the residuals of an error distribution by regressing the squared residuals with the independent variables. The BP test is chi-squared with $\mathrm{k}$ degrees of freedom, where $k$ is the number of independent variables. The P-values associated with the computed BP test statistic are shown in table 2. Values closer to 0 suggest a stronger departure from homoscedasticity in the distribution of residuals for the model.

At the Gresham station, models 1, 2, and 5 failed to reject the null hypothesis of homoscedasticity at a significance level of 0.05 . For all other models, the null hypothesis is rejected, and the model residual distribution is considered heteroscedastic. At the Milwaukie station, models 2, 3, and 5 failed to reject the null hypothesis of homoscedasticity at a significance level of 0.05 . For all other models, the null hypothesis is rejected, and the model residual distribution is considered heteroscedastic.

\section{Selection of Model}

Models 2 and 5 were eliminated from consideration due to their relatively poor results from the linear regression diagnostic statistics. No models were eliminated based on the JB test. The BP test of homoscedasticity was rejected for most models. Models with turbidity as an independent variable appear to be less homoscedastic in their error distributions (table 2). However, models with turbidity as an independent variable tend to provide more accurate estimates (that is, lower RMSE, MAE, and MAPE) than models not employing turbidity as an independent variable. The extra accuracy gained by including turbidity as a regression variable far outweighs any diminished accuracy in forecasts and prediction intervals resulting from heteroscedasticity. Each diagnostic linear regression statistic was ranked for each station between models (for example, model 7 provided the lowest MAE value at the Gresham gaging station and was ranked first), and the average rank for each model computed. Model 6 was selected because it had the lowest average rank.

\section{References Cited}

Breusch, T.S., and Pagan, A.R., 1979, Simple test for heteroscedasticity and random coefficient variation: Econometrica (The Econometric Society), v. 47, no. 5, p. $1,287-1,294$.

Jarque, C.M., and Bera, A.K., 1980, Efficient tests for normality, homoscedasticity, and serial independence of regression residuals: Economics Letters, v. 6, no. 3, p. $255-259$.

Ott, R.L., and Longnecker, M., 2001, An introduction to statistical methods and data analysis: Pacific Grove, Calif., Wadsworth Group, 1,152 p. 
Publishing support provided by the U.S. Geological Survey Publishing Network, Tacoma Publishing Service Center

For additional information contact:

Director, Oregon Water Science Center

U.S. Geological Survey

2130 SW 5th Avenue

Portland, Oregon 97201

http://or.water.usgs.gov 
